\title{
FAIL BUT TRY AGAIN? \\ THE EFFECTS OF AGE, GENDER, AND MULTIPLE-OWNER EXPERIENCE ON FAILED ENTREPRENEURS’ REENTRY
}

\author{
Massimo Baù* \\ Jönköping International Business School - Jönköping University \\ Centre for Family Enterprise and Ownership - CeFEO \\ PO Box 1026 \\ SE-551 11 Jönköping, Sweden \\ Tel. +46 (0)36101813 \\ Fax. +46 (0)36160070 \\ Massimo.Bau@ju.se \\ Philipp Sieger \\ University of Bern \\ Engehaldenstrasse 4 \\ CH-3012 Bern, Switzerland \\ philipp.sieger@imu.unibe.ch \\ Kimberly A. Eddleston \\ D'Amore-McKim School of Business \\ Northeastern University \\ 209 Hayden Hall \\ Boston, MA 02115, USA \\ K.Eddleston@neu.edu \\ Francesco Chirico \\ Jönköping International Business School - Jönköping University \\ Centre for Family Enterprise and Ownership - CeFEO \\ PO Box 1026 \\ SE-551 11 Jönköping, Sweden \\ EGADE Business School, Tecnológico de Monterrey \\ Francesco.Chirico@ju.se
}

Keywords: entrepreneurship, failure, age, reentry, gender, ownership

*Corresponding author 


\title{
FAIL BUT TRY AGAIN? \\ THE EFFECTS OF AGE, GENDER, AND MULTIPLE-OWNER EXPERIENCE ON FAILED ENTREPRENEURS’ REENTRY
}

\begin{abstract}
We investigate what leads failed entrepreneurs to reenter entrepreneurship by taking a developmental career perspective. Specifically, we hypothesize that the age of failed entrepreneurs has a non-linear relationship with the likelihood of reentering entrepreneurship that follows different career stages (early, middle, and late). The gender of failed entrepreneurs and multipleowner experience in the failed firm are hypothesized to be moderators of this relationship. We test our hypotheses using a database consisting of the Swedish population, including 4,761 entrepreneurs who failed between 2000 and 2004. Analyzing their career paths over the years following their failure offers support for our theoretical expectations.
\end{abstract}

\section{INTRODUCTION}

While entrepreneurship in general and new venture creation in particular are considered to be of high social and economic importance (Audretsch \& Thurik, 2001; Levesque \& Minniti, 2006; Valliere \& Peterson, 2009), scholars generally agree that entrepreneurial performance outcomes are inherently uncertain and that failure is thus a central feature of entrepreneurship (Aldrich \& Martinez, 2001; Audretsch, Keilbach, \& Lehmann, 2006; Shepherd, 2003). In fact, most firms appear to fail, although the actual share is difficult to accurately determine (Sarasvathy, Menon, \& Kuechle, 2013). Failure has traumatic effects on the entrepreneur because it can induce depression and feelings of worthlessness. It can also damage an entrepreneur's reputation, social capital, and financial resources. Despite the potential negative effects of failure, some failed entrepreneurs try their hand again at entrepreneurship and create new ventures. As a result, it is important to understand what leads failed entrepreneurs to try again or to reenter entrepreneurship following failure. This issue is relevant not only because reentry is a common phenomenon but also because the evidence suggests that those firms created by serial entrepreneurs (Westhead, Ucbasaran, Wright, \& Binks, 2005) frequently perform better than firms created by novice entrepreneurs (cf. 


\section{Baù, Sieger, Eddleston, Chirico (forthcoming). Entrepreneurship Theory and Practice.}

Headd, 2003; Minniti \& Bygrave, 2001; Plehn-Dujowich, 2010). In recent years, researchers have investigated the determinants of failed entrepreneurs' decisions to create new firms and have focused, for instance, on factors related to grief recovery (Shepherd, 2003; Shepherd, Covin, \& Kuratko, 2009), learning from failure and enhanced human capital (e.g. Byrne \& Shepherd, 2015; Cope, 2011; Stam, Audretsch, \& Meijaard, 2009), and improved abilities to evaluate new opportunities (Davidsson \& Honig, 2003).

However, despite these laudable efforts, research on entrepreneurial reentry after failure remains “new and relatively unexplored” (Stam et al., 2009, p. 234), and there is a pressing need for additional theoretical and empirical research (cf. Amaral, Baptista, \& Lima, 2011; Hsu, Wiklund, \& Cotton, 2015; Sarasvathy et al., 2013). Specifically, although the existing literature agrees that choosing to create another firm after an entrepreneurial failure is deeply embedded in the failed entrepreneur's personal life course (cf. Dyer, 1994; Schein, 1978), there is not yet a life-cycle or career-cycle perspective on what leads failed entrepreneurs to become serial entrepreneurs. These cycles are inherently linked to an individual's age, yet research on age in the context of entrepreneurship has led to ambiguous and mixed findings (Amaral et al., 2011; Langowitz \& Minniti, 2007; Parker, 2004). In addition, although research shows that the career preferences and choices of men and women differ across career stages (Greller \& Stroh, 1995; Gutek \& Larwood, 1987; Powell \& Mainiero, 1992) and that men and women appear to pursue entrepreneurial careers for different reasons (Cliff, 1998; Eddleston \& Powell, 2008; Jennings \& Brush, 2013), gender has not been explicitly considered in the context of failed entrepreneurs and their decisions about reentering entrepreneurship. Such an omission is surprising given that women represent one of the fastest growing segments of the entrepreneurship population worldwide (Jennings \& Brush, 2013; Xavier, Kelly, Kew, Herrington, \& Vorderwülbecke, 2012; Zarya, 2015). Finally, the characteristics of the failed firm have rarely been explored in studies on entrepreneurial reentry. 


\section{Baù, Sieger, Eddleston, Chirico (forthcoming). Entrepreneurship Theory and Practice.}

To address these gaps, we assume a developmental career perspective (Hall, 1976, 2002) that characterizes individuals’ careers as consisting of three main stages: early, middle, and late. Because these stages are closely linked to an individual's age, we theorize that the age of a failed entrepreneur has a non-linear effect on the likelihood of the subsequent choice to reenter entrepreneurship (as opposed to wage employment) that generally follows the aforementioned three stages (Levinson, Darrow, Klein, Levinson, \& McKee, 1978; Sonnenfeld \& Kotter, 1982). More specifically, we expect that the relationship between a failed entrepreneur's age and the likelihood of reentering entrepreneurship is cubic and can thus be depicted as a sideways and inverted S-pattern (cf. Castrogiovanni, Combs, \& Justis, 2006; De Massis, Chirico, Kotlar, \& Naldi, 2014). In other words, we propose that the likelihood of reentering entrepreneurship depends on the age of a failed entrepreneur such that the corresponding relationship is positive in the earlycareer stage, turns negative in the mid-career stage, and becomes positive again in the late-career stage. Moreover, building on gender research that acknowledges the differences in the careers of male and female entrepreneurs (Eddleston \& Powell, 2008), we further propose that this cubic relationship is moderated by the failed entrepreneur's gender. Finally, we theorize that the magnitude of our main relationship in all career stages is contingent upon whether the failed entrepreneur shared ownership with multiple owners in the failed firm or if the failed venture was owned solely by the entrepreneur.

We test our hypotheses on a longitudinal data set obtained from Statistics Sweden that covers the Swedish population. We identified 4,761 entrepreneurs whose businesses failed between 2000 and 2004 and study their reentry propensity in the years following such failure. Using a Cox proportional hazard model, we find support for our theoretical predictions. Our work contributes to several streams of the literature. First, we contribute to the small but growing body of research on failed entrepreneurs' decisions to reenter entrepreneurship (cf. Amaral et al., 2011; Hsu et al., 
Baù, Sieger, Eddleston, Chirico (forthcoming). Entrepreneurship Theory and Practice.

2015; Sarasvathy et al., 2013; Stam et al., 2009). By extending the developmental career perspective to failed entrepreneurship, we are among the first to investigate how age influences a failed entrepreneur's decision to reenter entrepreneurship. In so doing, we add to the literature on the role of age in entrepreneurship by showing that age can have both positive and negative effects on the decision to reenter entrepreneurship. More specifically, we show how entrepreneurial preferences change across an individual's life course depending on their career stage. This finding also may explain previous mixed and ambiguous findings regarding age and entrepreneurship (cf. Blanchflower, Oswald, \& Stutzer, 2001; Levesque \& Minniti, 2006; Parker, 2004). Second, our findings regarding the cubic main relationship (a sideways and inverted S-pattern) contribute to research on serial entrepreneurs that aims to understand why certain individuals repeatedly try their hand at entrepreneurship despite obstacles and failure (Plehn-Dujowich, 2010; Wright, Robbie, \& Ennew, 1997). Third, we add to the literature on gender and entrepreneurship by illuminating how gender affects the relationship between the age of a failed entrepreneur and the decision to reenter entrepreneurship, thus highlighting the importance of gender in understanding entrepreneurship (Jennings \& Brush, 2013). Finally, we are among the first to offer detailed insights into how firm characteristics such as a multiple-owner structure affect entrepreneurship reentry decisions across career stages.

\section{THEORETICAL FOUNDATIONS}

The pursuit of entrepreneurial opportunities is naturally linked with high uncertainty and risk (Venkataraman, 1997). As a consequence, business failure is common in entrepreneurship (McGrath, 1999; Shane, 2009; Wiklund, Baker, \& Shepherd, 2010). In fact, the careers of entrepreneurs have been described as “fraught with business failure” (Dyer, 1994, p. 15). In basic terms, business failure occurs when a firm becomes insolvent and thus cannot continue to operate 


\section{Baù, Sieger, Eddleston, Chirico (forthcoming). Entrepreneurship Theory and Practice.}

(Shepherd, Douglas, \& Shanley, 2000). Although scholars generally agree that a considerable proportion of businesses fail, the actual share is unclear and difficult to determine (cf. Sarasvathy et al., 2013; Shepherd, 2003).

The career of an entrepreneur, however, does not necessarily end with failure (Plehn-Dujowich, 2010). Failure is not a "one-way exit" but rather a "revolving door," with failed entrepreneurs commonly reentering entrepreneurship (Stokes \& Blackburn, 2002). Many entrepreneurs, in fact, start a number of unsuccessful businesses before launching a successful one (Ronstadt, 1982). Starting a new firm, exiting, and starting another in sequential order has been termed "serial entrepreneurship” (cf. Sarasvathy et al., 2013; Ucbasaran, Westhead, \& Wright, 2006; Westhead et al., 2005). A serial entrepreneur is thus different from a first-time founder (novice entrepreneur) or an entrepreneur who owns and operates multiple businesses in parallel (portfolio entrepreneur); serial and portfolio entrepreneurs, in turn, both fall into the category of habitual entrepreneurs (cf. Plehn-Dujowich, 2010; Westhead et al., 2005; Westhead \& Wright, 1998).

Serial entrepreneurship is a common phenomenon in the entrepreneurship landscape (Hyytinen \& Ilmakunnas, 2007; Plehn-Dujowich, 2010; Sarasvathy et al., 2013; Ucbasaran et al., 2006) and is deemed to be important for wealth creation (Rosa \& Scott, 1996), job creation (Westhead et al., 2005), and general economic performance (Westhead, Ucbasaran, \& Wright, 2003). Consequently, a growing body of literature has examined the characteristics, behaviors, and entry/reentry decisions of serial entrepreneurs (e.g., Amaral et al., 2011; Ucbasaran et al., 2006; Westhead et al., 2005; Wright et al., 1997). Although serial entrepreneurs may have exited their previous businesses for reasons other than failure - for instance, through a sale or for personal reasons (cf. DeTienne \& Cardon, 2012; Headd, 2003; Wennberg, Wiklund, DeTienne, \& Cardon, 2010) - we focus only on failed entrepreneurs based on the frequency of new venture failure outlined above. 


\section{Baù, Sieger, Eddleston, Chirico (forthcoming). Entrepreneurship Theory and Practice.}

Failure can be a double-edged sword with respect to entrepreneurial reentry. On the one hand, having failed may discourage entrepreneurs from starting another business because a business failure represents a personal loss that can lead to a negative emotional response that is similar to the grief experienced with the loss of a loved one (DeTienne \& Chirico, 2013; Shepherd, 2003). Thus, business failure can be a traumatic event that dampens the motivation to try again and that reduces confidence, self-efficacy, and risk-taking propensities (Cave, Eccles, \& Rundle, 2001; Shepherd, 2003). In many cultures, failure might also be stigmatized (Stokes \& Blackburn, 2002). Moreover, business failure is likely to deplete the entrepreneur's financial resources, which constrains the establishment of a new business (Shepherd et al., 2009; Stam et al., 2009), and acquiring equity and debt capital might in turn become more difficult (Lee, Peng, \& Barney, 2007). Finally, in addition to the financial and emotional costs, business failure can lead to social and relationship costs (Cope, 2011).

On the other hand, some failed entrepreneurs “move on” to create new businesses (Schutjens \& Stam, 2006; Stam et al., 2009). Further, it has been argued that the firms of serial entrepreneurs who have experienced previous failure perform better than those created by novice entrepreneurs (Blanchflower \& Oswald, 1998; Headd, 2003). As such, the failure of one's firm is not always the end of an entrepreneur's career path. While some scholars question the learning effects from previous entrepreneurial efforts (cf. Coad, Frankish, Roberts, \& Storey, 2013; Frankish, Roberts, Coad, Spears, \& Storey, 2013), others maintain that important lessons can be learned from failure (Alvarez \& Parker, 2009; Cope, 2005) and that, in fact, an entrepreneur may learn more from failure than from success (McGrath, 1999). For example, an entrepreneur's business failure can result in increased human capital (cf. Cope, 2011; Minniti \& Bygrave, 2001), enhanced abilities in judging the relevance of information (Cooper, Folta, \& Woo, 1995) and in assessing the value of entrepreneurial opportunities (Davidsson \& Honig, 2003), additional skills that speed up business 


\section{Baù, Sieger, Eddleston, Chirico (forthcoming). Entrepreneurship Theory and Practice.}

creation (Davidsson \& Honig, 2003), and restraints on overconfidence (Hayward, Forster, Sarasvathy, \& Fredrickson, 2010; Ucbasaran, Wright, \& Westhead, 2003). In addition, the general ability to recover from grief caused by business failure is important in fostering resilience (Shepherd, 2003; Shepherd et al., 2009). Therefore, failed entrepreneurs may be in a unique position to start successful new businesses (Shepherd et al., 2009).

Sarasvathy et al. (2013) call for further theoretical development and empirical studies of business failure and serial entrepreneurship that investigate the behavior of entrepreneurs beyond a one-time (failed) entrepreneurial experience. Similarly, there has been a call for a dynamic perspective regarding entrepreneurial careers over an individual's life course (Sonnenfeld \& Kotter, 1982), as many entrepreneurs' careers do not begin with entry and end with exit but instead consist of multiple entries and exits along a career path (cf. DeTienne, 2010; Nordqvist, Wennberg, Baù, \& Hellerstedt, 2013). To address these calls, we apply a developmental career perspective (Hall, 1976, 2002) that views an entrepreneurial career as influenced by a person's age-related career stage.

A developmental career perspective seems appropriate because it regards a career as the evolving sequence of an individual's work experiences over time (Hall, 1976, 2002). This perspective suggests that an individual's career is dynamic and is characterized by different needs, values, and motivators that are prioritized at different stages in a life course. For example, Levinson's (1986; 1978) model of career development explains how critical concerns about the self, career, and personal relationships are confronted at predictable times in life. As a result of these confrontations, career preferences and intentions often change, thereby leading to shifts in an individual's career decisions (Levinson, 1986; Levinson et al., 1978; Ornstein \& Isabella, 1990). Indeed, research suggests that entrepreneurial intentions and preferences change across a person's life course (Dyer, 1992; Kautonen, Down, \& Minniti, 2014; Levesque \& Minniti, 2006). 


\section{Baù, Sieger, Eddleston, Chirico (forthcoming). Entrepreneurship Theory and Practice.}

Specifically, the developmental career perspective proposes that an individual's career consists of three sequential stages that are inherently linked to an individual's age: early, middle, and late (Dyer, 1994; Hall, 1976, 2002).

Although research has investigated the relationship between an individual's age and the likelihood of starting (and/or acquiring) a new business (Coate \& Tennyson, 1992; Langowitz \& Minniti, 2007; Levesque \& Minniti, 2006; Rees \& Shah, 1986; Ucbasaran et al., 2003), little is known about the role of age in predicting whether individuals will reenter entrepreneurship after experiencing business failure. While some research shows that the likelihood of starting a business increases with age up to a certain point and then decreases in the late-career stage (Levesque $\&$ Minniti, 2006; Parker, 2009), other studies suggest that entrepreneurship is positively related to age, thus recognizing the "Gray Wave" of entrepreneurs who are over 50 years of age and launch new ventures (Praag \& Ophem, 1995; Rafter, 2010; Singh \& Ronch, 2011). Taken together, this research highlights how entrepreneurs' motives in the early-career stage are often different from those in the late-career stage. Nonetheless, it is not known how these individuals are likely to react if their new venture fails and whether failure during a particular career stage serves to motivate or dissuade an entrepreneur from further entrepreneurship.

In addition, given the vast amount of research that proposes that men and women have different needs, values, and motivations in different career stages (Greller \& Stroh, 1995; Gutek \& Larwood, 1987; Martins, Eddleston, \& Veiga, 2002; Powell \& Mainiero, 1992), we would be remiss if we did not explore how gender influences failed entrepreneurs' reentry into entrepreneurship. To the best of our knowledge, explicit theorizing and in-depth empirical studies on the effect of gender on failed entrepreneurs' decisions to reenter entrepreneurship across career stages are lacking, resulting in a notable gap in the literature, which is particularly important to fill based on the demonstrated importance of gender to entrepreneurship (Jennings \& Brush, 2013; Verheul, 
Baù, Sieger, Eddleston, Chirico (forthcoming). Entrepreneurship Theory and Practice.

Uhlaner, \& Thurik, 2005). Additionally, we believe that it is imperative to consider the characteristics of the failed firm (Kalleberg \& Leicht, 1991) because research on entrepreneurial failure suggests, for instance, that grief, regret and the recovery process may be less severe when the failed business was owned by multiple owners who can share the emotional and financial costs (Cope, 2011; Stokes \& Blackburn, 2002). Thus, a key aspect that may predict whether a failed entrepreneur will reenter entrepreneurship is whether the unsuccessful business was owned solely by the entrepreneur or co-owned with other individuals.

\section{DEVELOPMENT OF HYPOTHESES}

\section{Individual's Age, Career Stages, and Entrepreneurial Reentry}

According to the developmental career perspective (Hall, 1976, 2002), an individual's career is a dynamic process in which the relative importance of needs, values, and motivators - as well as preferences - changes across career stages. Career preferences thus change with age, and the propensity for entrepreneurship is not static throughout the life course. As a rule of thumb, the early-career stage describes individuals who are younger than approximately 40 years, the midcareer stage includes those who are approximately 40-50 years old, and the late-career stage includes those who are over 50 years of age (Cohen, 1991; Gibson, 2003; Greller \& Simpson, 1999). These ages correspond with the view that mid-career is approximately 20 years into one's professional career (Arvey, 1996; Schneer \& Reitman, 1995). These age-based career stages are closely related to Super's (1957) model of career development, which consists of an early explorative period, a middle period of stabilization and then maintenance/revitalization, and finally a late period that involves a gradual withdrawal from the work environment (Ornstein \& Isabella, 1990; Slocum \& Cron, 1985). Below, we extend the developmental career perspective to 


\section{Baù, Sieger, Eddleston, Chirico (forthcoming). Entrepreneurship Theory and Practice.}

entrepreneurship by discussing how age is expected to influence entrepreneurial reentry after failure over the three different career stages.

Early-career stage: The early-career stage is characterized by individuals' full-time entry into the labor force and the initial exploration of different career opportunities and work activities (Cohen, 1991; Lam, Ng, \& Feldman, 2012; Levinson, 1986). During the early-career stage, individuals seek to build competencies and to assess their skills for purposes of making an occupational choice (Super, 1957). This period is generally a time of great uncertainty in which individuals question their professional competence and contemplate whether to commit to a particular organization or occupation (Slocum \& Cron, 1985). It is also a time when the cost of changing career paths is at its lowest because less organizational or occupation-specific human capital has accumulated compared with later career stages (Gimeno, Folta, Cooper, \& Woo, 1997; Ng \& Feldman, 2007). Accordingly, as failed entrepreneurs progress through the early-career stage, their propensity for starting a new venture should increase steadily because they are continuing to explore their occupational interests while simultaneously building and assessing their competencies and skills. In addition, their sunk costs in a particular organization or occupation are relatively low.

An early experience with entrepreneurship is often viewed as a trial-and-error learning experience (Eisenhardt \& Tabrizi, 1995) and an opportunity to learn-by-doing (Minniti \& Bygrave, 2001). Failing as a young entrepreneur has little stigma because society tends to associate youth with trial and exploration (Super, 1957), where “failure can happen.” Less stigmatization should allow young failed entrepreneurs to better restore and enhance their social capital in the years following failure (Cope, 2011), which, in turn, will continuously increase the likelihood that they identify new entrepreneurial opportunities and thus reenter entrepreneurship after failure. On a related note, research shows that the emotional force of regret tends to be weak for young adults 


\section{Baù, Sieger, Eddleston, Chirico (forthcoming). Entrepreneurship Theory and Practice.}

(Stewart \& Vandewater, 1999). Furthermore, individuals in their early-career stage are most likely to perceive that they can fix or mend a regrettable situation through their own actions, such as by starting a new business (Jokisaari, 2003). Building on these considerations, age should be positively related to the likelihood of reentering entrepreneurship (as opposed to wage employment) during the early-career stage.

Mid-career stage: The same relationship between age and likelihood of reentry to entrepreneurship may not predominate for those progressing in the mid-career stage. The midcareer stage is a period during which one expects to gain a sense of occupational mastery and to develop successful career routines (Levinson, 1986). It is an important phase in individuals' careers because it is a time during which they reflect on the difference between what has been achieved and what they desire within the context of what time remains. The mid-career stage is thus characterized by reflection, reassessment and recalibration (Gordon, Beatty, \& Whelan, 1999; Lachman, 2001). More specifically, although progression through the mid-career stage is typically associated with an increasing desire for stability - based on the high degree of family responsibilities that typically accompany this age group (Martins et al., 2002; Slocum \& Cron, 1985; Williams \& Savickas, 1990) - this progression can also instigate life regrets that motivate change and “midcourse corrections” (Newton, Torges, \& Stewart, 2012; Staudinger, 2001; Stewart \& Vandewater, 1999). Lachman explains how "the individual either fulfills or ultimately fails and has to give up many long-standing ambitions” during mid-career (2001, p. 354).

Mid-career is thus viewed as a complex period because depending on the individual's assessment of achievement, it can be characterized as stable, with a focus on maintaining the individual's level of success, or as transformative, with dramatic shifts aimed at altering the individual's career path to add additional and new achievements (Hall, 1986). This perceived aspiration-achievement gap is a key reason that individuals make career changes during mid-career 


\section{Baù, Sieger, Eddleston, Chirico (forthcoming). Entrepreneurship Theory and Practice.}

(Hall, 1976; Herr \& Cramer, 1988). As a result, failed entrepreneurs may be more likely to give up their entrepreneurial career ambitions in exchange for wage employment as they progress through the mid-career stage.

Indeed, a sense of failure during mid-career often serves to stimulate a need to re-explore and re-establish one's career (Hall, 1986) because a lack of achievement during this stage can lead to angst and disappointment (Levinson, Darrow, Klein, Levinson, \& McKee, 1974). Furthermore, individuals in the mid-career stage are likely to question their past choices (Gould, 1972) and to come to see their past ambitions as unrealistic (Lachman, 2001). Because of mid-career regrets and the recognition that a desired career path may be impossible, as individuals progress through the mid-career stage they often try to revise their past career decisions by changing career paths (Levinson et al., 1978). As such, during the mid-career stage, the likelihood of reentry to entrepreneurship, compared with wage employment, is expected to decline with age.

Late-career stage: With progression in terms of age into the late-career stage, however, we may see a resurgence in entrepreneurship after previous failure. Those in the late-career stage have moved beyond mid-career reflections and aspiration-achievement gap regrets and instead have begun to think more positively about past career decisions and to rationalize their career trajectory (Schacter, 2001). These individuals emphasize the facets of their lives that are fulfilling and reconcile themselves with those that were not (Levinson et al., 1974). As late-career stage adults age, they become quite skilled at regulating their emotions in response to negative events (Charles \& Carstensen, 2007; Gross, 2008) and appear to give a disproportionate weight to positive memories and less weight to negative memories (Västfjäll, Peters, \& Bjälkebring, 2011).

More specifically, research on age and emotions suggests that as individuals progress through late adulthood, their emotions shift from predominantly negative to positive, and they take on a more serene and content posture (Ross \& Mirowsky, 2008). Rather than deal with obstacles by 


\section{Baù, Sieger, Eddleston, Chirico (forthcoming). Entrepreneurship Theory and Practice.}

attempting to emotionally suppress and ignore them which then causes negative emotions to linger and accumulate, late-age adults tend to use the cognitive reappraisal emotion regulation strategy (John \& Gross, 2004). This strategy involves changing the way the individual thinks about the stressful event that therefore modifies and lessens its emotional impact (John \& Gross, 2004). As a result, those progressing through the late-career stage will likely see problems as transient and manageable and to feel less demoralized by personal crises. Indeed, late-age adults have been found to come to terms with regret-inducing events by either stressing the positive aspects of the event or by reinterpreting the event more positively (Kennedy, Mather, \& Carstensen, 2004; Kryla-Lighthall \& Mather, 2009; Mather \& Johnson, 2000). Because research suggests that ex-entrepreneurs quickly return to entrepreneurship following a positive founding experience (Amaral et al., 2011), failed entrepreneurs progressing through the late-career stage may also be more willing to reenter entrepreneurship based on their increasing ability to regulate their negative emotions and focus on positive memories.

In addition, there may be a positive relationship between age during the late-career stage and reentry to entrepreneurship after failure due to changes in one's self-concept, career values and human capital. Although the early-career stage is associated with creating a viable self-concept, and the mid-career stage is associated with refining that concept, the late-career stage is associated with seeking to enhance and affirm one’s self-concept (Gibson, 2003). During the late-career stage, individuals increasingly come to know who they are and who they are not (Greller \& Simpson, 1999). Unlike the mid-career stage, which can be a period of substantial change (Hall, 1986; Lachman, 2001; Levinson et al., 1978), the late-career stage tends to focus on re-invigoration, learning, and growing in pre-existing directions that are consistent with the individual's selfconcept (Greller \& Simpson, 1999; Levinson, 1986). It is also a time when individuals emphasize intrinsic motivation and work enjoyment (Greller \& Simpson, 1999; Sturges, 1999) and seek to 


\section{Baù, Sieger, Eddleston, Chirico (forthcoming). Entrepreneurship Theory and Practice.}

pursue emotionally-meaningful goals (Fung \& Carstensen, 2004). Therefore, as failed entrepreneurs progress in the late-career stage, their intensified self-concept as an entrepreneur and focus on enjoying their work are likely to encourage their reentry into entrepreneurship rather than wage employment.

Finally, an entrepreneurial career may be failed entrepreneurs' only option as they advance in the late-career stage because they might have high entrepreneurial-specific human capital that hampers them from changing occupations (Amaral et al., 2011). Additionally, their older age provides them with more substantial work experience, social networks and financial capital that should aid them in identifying entrepreneurial opportunities as well as in establishing a new venture (Amaral et al., 2011; Kautonen et al., 2014; Parker, 2004). Entrepreneurship can also be an alternative to retirement for those who are unable or unwilling to retire (Greller \& Simpson, 1999; Quinn, 1980). As these individuals near retirement age, they may see entrepreneurship as a way to keep active and also benefit society with their accumulated human and social capital (Webster \& Walker, 2005).

Taken together, we propose that the relationship between failed entrepreneurs' age and the likelihood of reentering entrepreneurship (compared with entering into wage employment) follows a distinctive pattern such that it is positive during the early-career stage, negative during the midcareer stage, and positive again during the late-career stage. Put differently, we argue that the likelihood of reentry increases with age in the early-career stage, decreases with age in the midcareer stage, and then increases with age in the late-career stage. As such, we hypothesize a cubic relationship between a failed entrepreneur's age and entrepreneurial reentry that has two inflection points and that resembles a sideways and inverted S pattern (cf. Castrogiovanni et al., 2006; De Massis et al., 2014): 
Baù, Sieger, Eddleston, Chirico (forthcoming). Entrepreneurship Theory and Practice.

Hypothesis 1: A failed entrepreneur's age is related to the likelihood of entrepreneurial reentry such that (1a) the relationship is positive during the early-career stage, (1b) the relationship is negative during the mid-career stage, and (1c) the relationship is positive during the late-career stage.

\section{The Moderating Effect of Gender}

Although most research finds that men are more likely to start a business than women (Chen, Greene, \& Crick, 1998; Chowdhury \& Endres, 2005; Gatewood, Shaver, Powers, \& Gartner, 2002), women now represent one of the fastest growing segments of the entrepreneurship population worldwide (Jennings \& Brush, 2013; Xavier et al., 2012; Zarya, 2015). Researchers often explore the different reasons why men versus women start businesses (DeMartino \& Barbato, 2003; Jennings \& Brush, 2013) as well as their different sources of career satisfaction from business ownership (Brush, 1992; Eddleston \& Powell, 2008). While progress has been made in understanding the different reasons that men and women become entrepreneurs, to the best of our knowledge, no study has explored gender differences in entrepreneurial reentry after failure. Because entrepreneurship is regarded as a gendered process (Eddleston \& Powell, 2008), male and female entrepreneurs are likely to respond differently to their business' failure.

For example, although gender was only used as a control in a study on entrepreneurs' reaction to business failure, the findings revealed that women experience more grief than men after the failure of their business (Jenkins, Wiklund, \& Brundin, 2014). Women appear more intropunitive than men, i.e., women are more likely to judge themselves excessively harshly and as failures (Dattner \& Hogan, 2011). For instance, women are more influenced by negative feedback, whereas men are more influenced by positive feedback (Roberts \& Nolen-Hoeksema, 1989). Differences in how men and women react to failure has been referred to as men's "self-enhancing bias" and women’s “self-derogatory bias” (Bar-Tal \& Frieze, 1977; Levine, Gillman, \& Reis, 1982). Accordingly, because women appear to be more grief-stricken and negatively affected by failure, 


\section{Baù, Sieger, Eddleston, Chirico (forthcoming). Entrepreneurship Theory and Practice.}

the likelihood of women's reentry into entrepreneurship after a failure may be different from that of men.

Further, in applying the developmental career perspective to male and female entrepreneurs' reentry to entrepreneurship, we must consider gender differences across the career stages. The careers of female entrepreneurs are less linear than their male counterparts due to life-stage events associated with motherhood and family considerations (Lewis, Harris, Morrison, Ho, Jawahar, \& Al Ariss, 2015). Research has shown that the careers of women are inherently complex (Betz \& Fitzgerald, 1987; Ornstein \& Isabella, 1990; Powell \& Mainiero, 1992), whereas those of men are more defined and bound by masculine gender role expectations that emphasize an upward trajectory and "breadwinner” status (Hostetler, Sweet, \& Moen, 2007; Jennings \& McDougald, 2007; Powell \& Graves, 2003). However, research also reveals that men and women undergo a type of role reversal during mid-career whereby men begin to change their career pace and emphasize their personal lives while women begin to feel freer to pursue career goals (Gordon \& Whelan, 1998; Greller \& Stroh, 1995; Martins et al., 2002; Powell \& Graves, 2003). In other words, whereas men tend to emphasize personal achievement throughout their careers, women tend to emphasize career achievement more as they age (Stroh \& Reilly, 1999; Sturges, 1999). Further, mid-career is the time when men feel the most conflict between work and family responsibilities (Cournoyer \& Mahalik, 1995). Mid-career is the stage in a man’s career when he is likely to feel pressure related to fulfilling the "breadwinner" role because this stage is typically characterized by the greatest financial and family responsibilities (Levinson et al., 1978). Accordingly, men in the mid-career stage may show the lowest rate of entrepreneurial reentry after experiencing entrepreneurial failure.

Conversely, women often become much more involved in their careers during the mid-career stage because midlife is typically associated with an end to child-bearing (Powell \& Graves, 2003; 
Baù, Sieger, Eddleston, Chirico (forthcoming). Entrepreneurship Theory and Practice.

Powell \& Mainiero, 1992). Additionally, work experience appears to boost women's selfconfidence as their careers develop, which encourages women in their mid- and late-career stages to dedicate more time and energy to their careers (Greller \& Stroh, 1995; Powell \& Graves, 2003; Stroh \& Reilly, 1999; Sturges, 1999). Therefore, although women's rate of entrepreneurial reentry may be lower than men's rate of reentry in general, unlike their male counterparts, we expect that the likelihood that failed female entrepreneurs will reenter entrepreneurship - as opposed to wage employment - will increase with age during all three career stages. In other words, while we expect a cubic relationship between a male entrepreneur's age and entrepreneurial reentry that resembles a sideways and inverted S pattern, for females we expect age to be positively related to entrepreneurial reentry across all career stages. Hence, we propose:

Hypothesis 2: Gender moderates the relationship between a failed entrepreneur's age and the likelihood of entrepreneurial reentry such that women's likelihood of reentry increases with age across all career stages, while men's likelihood of reentry increases with age during the early-career stage, decreases with age during the mid-career stage, and increases with age during the late-career stage.

\section{The Moderating Effect of a Multiple-Owner Experience}

One distinguishing feature of a failed business that may affect whether an individual turns to entrepreneurship again is whether the business had been owned by a single entrepreneur (sole owner) or by multiple owners (Francis \& Sandberg, 2000; Harper, 2008; Lechler, 2001; West, 2007). Research has suggested that the grief and recovery process after business failure may be less severe for entrepreneurs with co-owners, versus those without, due to shared emotional and financial costs (Cope, 2011; Stokes \& Blackburn, 2002). However, a developmental life-stage perspective suggests that due to changes in attributions (Blanchard-Fields, 1994; Follett \& Hess, 2002) and coping strategies with age (Aldwin, Sutton, Chiara, \& Spiro, 1996; Heckhausen, 2011), a multiple-owner experience may have a different effect on the entrepreneurial reentry of early-, 


\section{Baù, Sieger, Eddleston, Chirico (forthcoming). Entrepreneurship Theory and Practice.}

mid- and late-career entrepreneurs. Attribution theory seeks to explain how individuals make sense of their behavior, others' actions, and events that have previously occurred (Heider, 1958; Weiner, 1974). Referred to as attribution biases, the theory describes why some people "protect their selfesteem by taking credit for success and denying responsibility for failure” (Heckhausen \& Schulz, 1995; Luginbuhl, Crowe, \& Kahan, 1975; Zuckerman, 1979, p. 254). Due to attribution biases, some failed entrepreneurs may therefore "blame others" to protect their self-esteem. Accordingly, the presence of multiple owners offers failed entrepreneurs a salient external actor (or actors) to whom they can attribute their failure.

However, causal attributions are not stable throughout an individual's life course; attributional complexity peaks in midlife, and young adults are most likely to suffer from attributional biases (Follett \& Hess, 2002; Gilbert \& Malone, 1995). Additionally, in negative outcome situations, older adults are more likely than younger or middle-aged adults to "blame" a person for an outcome (Blanchard-Fields, 1994). Such differences across adult development stages are also found in research on coping with failure. Below, we draw from the literature on age differences in attributions and coping strategies to argue that whether a multiple-owner experience increases or decreases the likelihood of a failed entrepreneur's reentry into entrepreneurship depends on the entrepreneur's age.

When evaluating the causes of problems, young adults are more likely to make fundamental attribution errors than those in middle or late adulthood (Follett \& Hess, 2002). In other words, when evaluating another's behavior, young adults tend to focus solely on that person's actions and to not consider situational factors surrounding the circumstances (Follett \& Hess, 2002; Gilbert \& Jones, 1986). This tendency by young adults to accept a dualistic, right-versus-wrong structure of reality allows them to attribute negative events to an individual and to downplay or even omit environmental factors (Blanchard-Fields, 1994). The attribution biases of young adults also allow 


\section{Baù, Sieger, Eddleston, Chirico (forthcoming). Entrepreneurship Theory and Practice.}

them to avoid self-blame for problems and to believe that they can fix problems through their own actions. When applied to failed entrepreneurs, research suggests that those in their early-career stage may cope more easily with the loss of their business when multiple owners were involved because the failure can be blamed on the co-founder(s), thereby protecting the young adult's selfesteem. As such, those progressing in the early-career stage are most likely to cope with problems (i.e., failure) by attempting to change their circumstances through their own actions (Brandtstadter \& Renner, 1990; Heckhausen, 2011) and to suffer from fundamental attribution biases (Follett \& Hess, 2002) that allow them to blame others for their failure. Consequently, when failed entrepreneurs in the early-career stage have had a multiple-owner experience, the negative impact of failure will be less severe than if they had experienced a single-owner business failure, and thus, their reentry into entrepreneurship is expected to increase over time. This reasoning suggests that having had a multiple-owner experience will augment the positive relationship between age and the likelihood of reentry during the early-career stage.

In comparison, just as the developmental career literature describes the mid-career stage as a time for readjustment and transition (Hall, 1986; Levinson et al., 1978; Newton et al., 2012), the adult development literature portrays this stage as marked by attributional complexity (Follett \& Hess, 2002) and changes in coping strategies (Heckhausen, 2011). Middle-aged adults are most likely to consider both the person and the environment when making attributions and are less likely than younger and older adults to display biases and causal attributions (Follett \& Hess, 2002). As such, failed entrepreneurs progressing through their mid-career stage would likely attribute their business failure to a multitude of interacting causes and not place the primary cause of failure on their co-owner(s), which is consistent with research that suggests that individuals in midlife are most likely to blame themselves for problems when compared with younger and older adults (Aldwin et al., 1996). Further, because regret is particularly strong for those progressing through 


\section{Baù, Sieger, Eddleston, Chirico (forthcoming). Entrepreneurship Theory and Practice.}

the mid-career stage (Stewart \& Vandewater, 1999), the presence of co-founders may make their experience of failure particularly burdensome, and the entrepreneur may even feel guilty for the failure. For mid-career failed entrepreneurs with a multiple-owner experience, it will thus be more difficult and take longer to recover from the loss of their business. Thus, although a multiple-owner experience is expected to strengthen the positive relationship between age and entrepreneurial reentry for those in the early-career stage, it is expected to strengthen the negative relationship between age and entrepreneurial reentry for those in the mid-career stage.

Studies on adult development reveal that older adults cope with failure and life problems in a unique manner (Blanchard-Fields, 1994; Brandtstadter, Wentura, \& Greve, 1993; Heckhausen, 1997; Toussaint, Williams, Musick, \& Everson, 2001). As an individual progresses past the midcareer stage through later adulthood, the individual relies more and more on self-protective coping strategies that include positive reframing and reappraisals of failure events (Wrosch, Heckhausen, \& Lachman, 2000) as well as social downgrading and downward social comparisons that enable the older adult to see himself or herself as better than others (Brim, 1992; Heckhausen \& Brim, 1997). The increased level of social downgrading and downward social comparisons with age may explain why older adults are less likely to blame themselves for failures than younger adults in the mid-career stage (Aldwin et al., 1996). Furthermore, when compared with young and middle-aged adults, older adults are less likely to consider contextual information when interpreting events (Follett \& Hess, 2002; Västfjäll et al., 2011) and are more likely to attribute the cause of a negative outcome to a person (Blanchard-Fields, 1994). Accordingly, as failed entrepreneurs progress in the late-career stage, those with multiple- versus single-owner experiences may be more likely to reenter entrepreneurship because they are more likely to place blame on others for the failure event and to use self-protective coping strategies as they age. Taken together, we propose: 
Baù, Sieger, Eddleston, Chirico (forthcoming). Entrepreneurship Theory and Practice.

Hypothesis 3: A multiple-owner experience moderates the relationship between a failed entrepreneur's age and the likelihood of entrepreneurial reentry such that, in comparison with those who experienced single-owner entrepreneurial failure, for those who have had a multiple co-owner entrepreneurial failure, the relationship is (3a) more positive during the early-career stage, (3b) more negative during the mid-career stage, and (3c) more positive during the latecareer stage.

\section{METHOD}

To test our hypotheses, we used three longitudinal databases maintained by Statistics Sweden, the official census bureau in Sweden. We constructed a longitudinal data set by combining the Labor Market Statistics (RAMS for its initials in Swedish) database, which provides yearly data on all firms registered in Sweden, and the Longitudinal Integration Database for Health Insurance and Labor Market Studies (LISA for its initials in Swedish) and the Jobbregistret (work register) databases, which provide yearly data on all Swedish inhabitants and income sources. Based on the available data, we focus on those Swedish entrepreneurs who experienced a failure during the 2000-2004 period, and we follow their careers until 2008. In line with the prior literature (Wennberg et al., 2010), we first define failed entrepreneurs as entrepreneurs whose firms have disappeared from the market without being sold or merged with another firm (i.e., the firm had been shut down). In addition, following Bradley et al. (2011), we used the Altman's Z-score multivariate financial model to investigate the likelihood of bankruptcy (Altman, 1968, 2000). We regarded entrepreneurs as failed when their company had a Z-score below 1.23 (the distress zone for private companies) in their last year of activity (cf. Altman, 2000). Taken together, our failed entrepreneurs were managing a firm that was in severe financial distress in the year before it was shut down (without being sold or merged), which constitutes a very narrow and strict definition of 


\section{Baù, Sieger, Eddleston, Chirico (forthcoming). Entrepreneurship Theory and Practice.}

failure (Bradley et al., 2011; Miller \& Reuer, 1996; Wennberg et al., 2010) ${ }^{1}$. Furthermore, while different career trajectories may exist following failure, we only consider failed entrepreneurs who became "regular" employees (i.e., engaged in wage employment) or started a new business after the failure; we thus excluded respondents who were unemployed or who retired after their entrepreneurial failure (cf. Hsu et al., 2015; Hyytinen \& Ilmakunnas, 2007; Sorensen \& Fassiotto, 2011; Stam, Audretsch, \& Meijaard, 2008). Given that the Swedish pension system offers a guaranteed pension that can be drawn beginning at age 65 for both men and women, we chose to consider only those individuals who were between 18 and 65 years of age at the time of reentry. Based on the data available, our final sample consisted of 4,761 failed entrepreneurs. The opportunity to use a data set that covers the entire population of a developed country such as Sweden offered us a unique and valuable setting to test our hypotheses (cf. Wennberg, Wiklund, Hellerstedt, \& Nordqvist, 2011; Wiklund, Nordqvist, Hellerstedt, \& Bird, 2013).

\section{Dependent and Independent Variables}

Entrepreneurial reentry was measured using a dummy variable. We analyzed whether the failed entrepreneur reentered entrepreneurship (coded "1") or became an employee (coded "0") in the years following his or her failure. Thus, for every year following the business failure, we have a separate dummy variable. Both a histogram and a detailed frequency table showed that the number of reentries into entrepreneurship was distributed evenly across the age spectrum.

The failed entrepreneur's age was considered at the time of reentry and was standardized for the analyses. Gender was coded as a dummy variable (" 1 ” for female and " 0 " for male). Multiple-

\footnotetext{
${ }^{1}$ Following Altman (2000), we used the following variables, notations, and operationalizations developed for private companies: $\mathrm{Z}$-score $=\mathrm{A} * 3.107+\mathrm{B} * .998+\mathrm{C} * .42+\mathrm{D} * .717+\mathrm{E} * .847$, where $\mathrm{A}=$ earnings before interest and taxes/total assets, $\mathrm{B}=$ sales/total assets, $\mathrm{C}=$ book value of equity/total liabilities, $\mathrm{D}=$ (current assets - current liabilities)/total assets, and $\mathrm{E}=$ retained earnings/total assets. The following is the convention for interpreting the Zscore in the literature and in practice: the "safe" zone for Z-scores is above 2.9, the "grey" zone for Z-scores is between 1.23 and 2.9, and the "distress" zone for Z-scores is below 1.23.
} 


\section{Baù, Sieger, Eddleston, Chirico (forthcoming). Entrepreneurship Theory and Practice.}

owner experience was identified by considering the number of owners involved in the failed business. In cases in which there were two or more owners, the variable was coded as " 1 " (indicating a multiple-owner experience). In cases in which there was only one owner, the corresponding dummy variable was coded as “0” (indicating no multiple-owner experience).

\section{Control variables}

We controlled for several individual- and firm-level variables that could affect our results. At the individual level, we accounted for the human capital of the failed entrepreneurs and its potential influence on the decision to reenter entrepreneurship based on education level, which we measured as the number of years of education (Ucbasaran et al., 2003) and which is an international standard for classifying education ${ }^{2}$. We also considered the failed entrepreneurs' entrepreneurial experience prior to their business failures by identifying whether they owned one or more other firms in the ten years before the failure of their most recent business (“ 1 ” if yes, "0" if no) (Wiklund \& Shepherd, 2008). To control for family characteristics that might have affected the failed entrepreneurs’ career choices (Ruderman, Ohlott, Panzer, \& King, 2002; Singh \& Greenhaus, 2004), we considered whether children 18 years old or younger were living in the same household as the individual (“0” if no, “ 1 ” if yes) (Eddleston \& Powell, 2008). We also controlled for the marital status of the individual ("1” if married, “0” if not) (Delmar \& Davidsson, 2000) and for family household wealth, which we defined as the family’s disposable income and calculated by summing the disposable incomes of all family members in a household (Fairlie \& Krashinsky, 2012). At the firm level, we controlled for the failed firm’s age at the time of failure (Gomez-Mejia, Haynes, Nunez-Nickel, Jacobson, \& Moyano-Fuentes, 2007). However, because firm age was not available as a specific number of years in our data set, we needed to use a binary variable that

\footnotetext{
${ }^{2}$ cf. http://www.uis.unesco.org/Education/Pages/international-standard-classification-of-education.aspx
} 
Baù, Sieger, Eddleston, Chirico (forthcoming). Entrepreneurship Theory and Practice.

indicated whether the firm was older (1) or younger (0) than 15 years at the time of failure. While not as specific as a firm's actual years in business, we believe that using this variable is reasonable because research has shown that conservative behaviors and negative outcomes emerge after approximately 15 years from establishment (Miller \& Shamsie, 2001).

\section{RESULTS}

We present descriptive statistics and correlations in Table 1. Inspection of the variance inflation factors (VIFs) showed that multicollinearity is not a concern in the study. All of the VIF coefficients are lower than 4.71 (mean = 2.34) (Belsley, Kuh, \& Welsch, 2005; Kutner, Nachtsheim, \& Neter, 2004). To test our hypotheses, we used a Cox proportional hazard model (Cleves, Gould, Gutierrez, \& Marchenko, 2008; Royston \& Lambert, 2011). An event history analysis allows us to predict both the timing and the occurrence of an event by incorporating longitudinal data with time-varying variables (Allison, 1984). In general, an event-history analysis is used to analyze the influence of predictor variables on the occurrence or non-occurrence and timing of specific events (Morita, Lee, \& Mowday, 1993). The dependent variable in a continuous time event history model is the hazard rate, which is the likelihood or risk of a given event occurring at time t, assuming that the event has not occurred prior to that time. Our dependent variable is dummy coded to indicate whether reentry occurred or not. We note that a key assumption of a Cox model is proportional hazard. We assessed this assumption by using the Stata command "stphtest” (cf. Cleves, Gould, Gutierrez, \& Marchenko, 2010). The result $\left(\chi^{2}=11.06, \mathrm{p}>\chi^{2}=0.27\right)$ is non-significant, indicating that the proportionality assumption is valid. Another assumption is linearity, which we tested by calculating the Martingale residuals. The smoother in the residual plot is flat and horizontal, confirming the assumption of linearity (Cleves et al., 2010; Mills, 2011). 


\section{Baù, Sieger, Eddleston, Chirico (forthcoming). Entrepreneurship Theory and Practice.}

We tested the hypotheses in eight models, as reported in Tables 2a and 2b. First, in Table 2a, we considered the control variables (Model 1), and then added the independent variables of interest, namely, entrepreneur’s age (Model 2), age squared (Model 3), and age cubed (Model 4), to test for curvilinear effects (Hypothesis 1). Osborne (2015) advocates this approach to test a sideways, inverted S pattern with two inflection points (and thus increasing and decreasing sections), which reflects our Hypotheses 1a-c (cf. Castrogiovanni et al., 2006; De Massis et al., 2014). Hypothesis 2 (gender) and Hypothesis 3 (multiple-owner experience) are tested in Table 2b. Model 5 introduces the main gender variable. We test the interaction effects of gender with entrepreneur's age and its squared and cubed terms in Model 6. The multiple-owner experience variable is added in Model 7. We test its interaction effects with failed entrepreneur's age and its squared and cubed terms in Model 8.

— Insert Tables 1 and 2a and $\mathrm{b}$ about here —

Hypothesis 1 proposes a cubic (a sideways and inverted S pattern) relationship between failed entrepreneurs' age and reentry to entrepreneurship. This relationship is supported in our analyses. Specifically, as shown in Model 4, age is positively and significantly related to the likelihood of entrepreneurial reentry, age’s squared term is negatively and significantly related to the likelihood of entrepreneurial reentry, and the cubed term of age is positively and significantly related to entrepreneurial reentry. To better understand the nature of this relationship, we plotted ${ }^{3}$ the results in Figure 1, which reflect the hypothesized cubic, sideways and inverted S pattern for age. That is, the likelihood of reentering entrepreneurship first increases through the early-career stage, then decreases through the mid-career stage, and finally increases again through the late-career stage.

\footnotetext{
${ }^{3}$ We plot the graphs in Figures 1-3 using the margins command in STATA.
} 
Baù, Sieger, Eddleston, Chirico (forthcoming). Entrepreneurship Theory and Practice.

Hypotheses 2 and 3 are tested in Models 6 and 8 of Table 2, respectively. The results demonstrate significant moderation effects for both gender and multiple-owner experience, as hypothesized. Our findings for Hypotheses 2 and 3 are supported by the results of our Likelihoodratio tests after estimation (Irtest in STATA), which show significant differences in model fit between the respective models. Specifically, the fit of Model 6 is significantly better than the fit of Model 5 ( $\mathrm{LR} \chi^{2}=6.86, \mathrm{p}>\chi^{2}=0.009$ ), and the fit of Model 8 is superior to the fit of Model 7 (LR $\left.\chi^{2}=6.04, p>\chi^{2}=0.014\right)$. To fully interpret these findings, we plotted the moderation effects of gender and multiple-owner experience in Figures 2 and 3, respectively. Both figures are discussed in detail in the discussion section below.

—Insert Figures 1, 2 and 3 about here-

\section{Robustness Tests}

To assess the robustness of the results, we performed several additional analyses. First, we adopted different empirical approaches. We relied on a pooled logit and complementary log-log analyses (cloglog in STATA), and the results were consistent with our main analysis. Additionally, we adopted a panel (random effects) probit regression model (xtprobit) and a discrete-time survival model (xtcloglog), and the results remained unchanged. In addition, we re-ran our analyses using other hazard models, including exponential, Gompertz, and Weibull models (Cleves et al., 2010). The results were all strong and consistent with the results obtained from the Cox model. Second, we verified whether the nonlinear relationship found in our study is instead a biquadratic curve, i.e., whether age quartic is significant. We only find support for the cubic term, and both the Akaike's information criterion (AIC) and the Bayesian information criterion (BIC) indices are lower for the model with the cubic term than for the model with the quartic term (see Table 2 and the corresponding notes). These results demonstrate that the model with the cubic term is preferable 


\section{Baù, Sieger, Eddleston, Chirico (forthcoming). Entrepreneurship Theory and Practice.}

to the model with the quartic term because smaller values of AIC and BIC denote better model fit. We further supported this finding by conducting a locally weighted regression (lowess in STATA); the lowess plot confirmed the cubic pattern of the smoothed age variable.

Third, we ran further robustness tests by considering a sample in which we excluded all entrepreneurs who owned a business prior to their failed business (serial entrepreneurs). All of our results were confirmed. Fourth, we considered a potential non-linear effect of education on our dependent variable by controlling for the squared and cubed values of our education variable. These additional variables are not significant, and our main findings are unchanged, both with regard to our main effect and with regard to our interaction effects. Fifth, to explore the mechanisms that drive our main pattern in more detail, we explored whether our family- and wealth-related control variables (children living in the same household, marital status, and family wealth) moderate the relationship between age and the likelihood of reentry, and we found no support for these relationships. Sixth, we used the xtile command in STATA to split our sample into three categories - early-, middle-, and late-career stages - and tested the linear effect of age in those subsamples. Our main results were confirmed (age in the early-career subsample has a positive effect, age in the mid-career subsample has a negative effect, and age in the late-career subsample has a positive effect on the likelihood of reentry). Finally, we checked for the potential effect of the time lag between failure and reentry by constructing an additional control variable that captures the years before reentry as an entrepreneur (with “0” indicating that the entrepreneur did not reenter). Adding this variable to our models did not change our results. Taken together, our results remained stable across different analytical procedures and model specifications, thereby providing additional support for our framework. 


\section{Baù, Sieger, Eddleston, Chirico (forthcoming). Entrepreneurship Theory and Practice.}

\section{DISCUSSION}

Drawing on the developmental career perspective (Dyer, 1994; Hall, 1976, 2002), our study aimed to investigate what leads failed entrepreneurs to try again by proposing a cubic relationship (a sideways and inverted S pattern) between failed entrepreneurs' age and their likelihood of entrepreneurial reentry. Testing this hypothesis on 4,761 failed entrepreneurs in Sweden confirmed our expectations across three corresponding career stages (Figure 1). Furthermore, we found evidence that both gender and a multiple-owner entrepreneurial experience moderate our main relationship across career stages (Figures 2 and 3).

These findings contribute to the literature in several ways. Most importantly, our study adds to research on failed entrepreneurs and their decision to start new ventures, thus becoming serial entrepreneurs. Although research has begun to identify different drivers of failed entrepreneurs' reentry, various scholars have explicitly called for additional research efforts in this regard (Amaral et al., 2011; Hsu et al., 2015; Sarasvathy et al., 2013; Stam et al., 2008). Specifically, Ucbasaran and colleagues (2008) encourage scholars to conduct research on habitual entrepreneurship (which includes serial entrepreneurship) using large, representative and longitudinal data sets (see also Parker, 2013). We addressed these calls by utilizing a data set that is highly representative in that it covers the entire Swedish population and includes a large number of failed entrepreneurs whose career paths were tracked longitudinally. This approach allowed us to treat neither entrepreneurship nor a return to employment after failure as final career destinations and instead to develop a dynamic perspective of entrepreneurial careers to explore entrepreneurial reentry. In fact, we show that business failure is not the final destination of many entrepreneurs; instead, the results show that reentry after failure is indeed a common phenomenon (Schutjens \& Stam, 2006; Shepherd, 2009). More specifically, we found that reentry was the choice of 1,192 failed entrepreneurs, which represented approximately $25 \%$ of our sample. Importantly, we are able to identify one main driver 


\section{Baù, Sieger, Eddleston, Chirico (forthcoming). Entrepreneurship Theory and Practice.}

and two contingency factors in the entrepreneurial reentry decision, which constitutes a major contribution to the literature on failed entrepreneurs and their reentry into entrepreneurship.

The main driver of the entrepreneurial reentry decision that we identified is the age of the failed entrepreneur. The application of the developmental career perspective (Hall, 1976, 2002) allowed us to consider the role of age across the three main stages of an individual's career. Specifically, treating age as a continuous variable allowed us to consider how the experiences and concerns that predominate during each career stage affect a failed entrepreneur's decision to reenter entrepreneurship over time. We are among the first to explicitly consider the role of age in the context of failed entrepreneurs' reentry decisions. Our theorizing in the context of different career stages and our empirical results indicate a unique and novel cubic relationship (a sideways and inverted S pattern) between age and reentry. These results show that age can have both positive and negative effects on the likelihood of reentry, with this effect crucially depending on the career stage of the failed entrepreneur. This finding is consistent with the observation that changes in preferences and behaviors occur over individuals’ life spans (Levesque, Shepherd, \& Douglas, 2002) and should therefore help to reconcile existing conflicting reports on the relationship between entrepreneurs' age and decisions to start a new business (e.g., Levesque \& Minniti, 2006; Parker, 2004; Quinn, 1980). Moreover, our findings contribute to the stream of literature that recognizes the important role of age in entrepreneurship (e.g., Coate \& Tennyson, 1992; Langowitz \& Minniti, 2007; Levesque \& Minniti, 2006; Ucbasaran et al., 2003).

In addition, we identified gender as a contingency factor that alters the relationship between the age of failed entrepreneurs and the likelihood of entrepreneurial reentry. While we illustrate the crucial role of gender in the entrepreneurship context in general (Jennings \& Brush, 2013), we are among the first to provide explicit theorizing and an empirical investigation of gender's role in the context of failed entrepreneurs and their potential reentry into entrepreneurship. Whereas the 


\section{Baù, Sieger, Eddleston, Chirico (forthcoming). Entrepreneurship Theory and Practice.}

literature generally agrees that women's propensity to engage in entrepreneurship is lower than that of men (cf. Reynolds, Carter, Gartner, \& Greene, 2004; Stam et al., 2008; Wagner, 2005), we are the first to show that the likelihood of entrepreneurial reentry following entrepreneurial failure differs between the genders. As shown in Figure 2, it is notable that at specific ages, women were as likely to return to entrepreneurship as their male counterparts, which highlights the importance of examining age as a continuous variable when exploring gender differences. Figure 2 also reveals that while men's likelihood of reentry increases with age in the early-career stage, decreases with age in the mid-career stage, and increases with age in the late-career stage, the likelihood of reentry for women increases through the mid-career stage and then plateaus. As such, our second hypothesis is only partially supported, as we expected the likelihood of women's entrepreneurial reentry to increase with age through the late-career stage. In other words, while our results revealed that failed male entrepreneurs' reentry into entrepreneurship reflects the career stage characteristics proposed by Levinson et al. (1974), including a discernable mid-career adjustment (Hall, 1986), failed female entrepreneurs have a distinct career pattern whereby their mid-career adjustment begins to occur at approximately age 35. As such, the mid-career adjustment differs for male and female entrepreneurs. While the mid-career adjustment for failed male entrepreneurs leads to a decline in entrepreneurial reentry, for failed female entrepreneurs, the mid-career adjustment appears to encourage entrepreneurship. These results indicate the crucial role that the mid-career stage plays in entrepreneurs' life cycles and their related career decisions (Lachman, 2001; Levinson, 1986) and call for additional research on the mid-career transitions of entrepreneurs.

The other factor that alters the relationship between age and the likelihood of entrepreneurial reentry is multiple-owner experience. To our knowledge, we are the first to link multiple-owner experience to the likelihood of reentry, which extends recent research on entrepreneurial teams (e.g., Harper, 2008; Schjoedt, Monsen, Pearson, Barnett, \& Chrisman, 2013; West, 2007). As 


\section{Baù, Sieger, Eddleston, Chirico (forthcoming). Entrepreneurship Theory and Practice.}

illustrated in Figure 3, our findings reveal that for failed entrepreneurs who have this experience compared with those who have not had this experience, the relationship between age and the likelihood of reentry is more positive in the early-career stage, more negative in the mid-career stage, and more positive in the late-career stage. In other words, in the mid-career stage, failing with co-owners seems to be particularly severe, which is likely due to a strong tendency for selfblame (Aldwin et al., 1996) that induces high emotional and social costs thereby preventing entrepreneurial reentry.

\section{Limitations and Future Research}

This study has certain limitations that can also help identify future research directions. Most importantly, we acknowledge that a multitude of factors may affect failed entrepreneurs' reentry decisions beyond age, gender, and multiple-owner experience that we cannot fully account for in our study. Although we made our best efforts to account for established factors with our control variables, future research could extend our work by explicitly considering potential drivers of reentry such as access to critical resources (Birley, 1985; Dyer, 1994) and family embeddedness considerations (Aldrich \& Cliff, 2003), which may in turn lead to enhanced resource access (Arregle, Batjargal, Hitt, Webb, Miller, \& Tsui, 2015), or the inability of failed entrepreneurs to find regular employment. Additionally, it would be interesting to directly examine how grief and grief recovery are related to age and gender considerations. Additionally, we note that age may induce individual-level psychological processes beyond those we highlight in this manuscript. While our arguments draw from the rich literature on differences among age-related career stages (i.e., Greller \& Simpson, 1999; Hall, 2002; Ornstein \& Isabella, 1990), future research should explicitly capture specific psychological factors associated with an entrepreneur's age, such as stress, regret and/or emotional turmoil (Levinson, 1978). In addition, we have only touched the surface on the role of organizational factors in predicting failed entrepreneurs' reentry (i.e., 


\section{Baù, Sieger, Eddleston, Chirico (forthcoming). Entrepreneurship Theory and Practice.}

multiple owner/sole owner). Future research should delve into this issue in more depth by investigating the ownership structure of failed businesses in more detail, such as whether the failed entrepreneur was a majority or minority owner. Also, it might be interesting to determine whether those entrepreneurs who failed in a multiple-owner experience try again with multiple owners or instead go solo. It is also necessary to explore failed entrepreneurs' attributions and coping strategies as well the performance of the subsequent business.

Furthermore, we limited our investigation to failed entrepreneurs; future research might explore to what extent our theorizing applies to entrepreneurs who have exited their previous business for non-economic reasons, such as utility considerations. Similarly, in line with the previous literature (e.g., Hsu et al., 2015), we did not consider failed entrepreneurs who were unemployed or who retired following their entrepreneurial failure. Nevertheless, it might be interesting to investigate the role that unemployment plays in the relationship between age and the likelihood of reentering entrepreneurship. Furthermore, while the time lag between failure and reentry does not affect our main relationships, as shown by our robustness tests, the underlying drivers of the time lag should be further explored. For example, it would be interesting to determine whether early or late reentries are more successful in the long run. Finally, we note that even though our data set offers unique advantages in terms of representativeness, size and longitudinal scope, it is limited to the context of Sweden. Because Sweden represents a developed European country, our results should be generalizable to a sufficient extent. Nevertheless, because business failure may be stigmatized to varying degrees across different countries and institutional contexts (Amaral et al., 2011), a replication of our results in different cultural settings would be valuable. 
Baù, Sieger, Eddleston, Chirico (forthcoming). Entrepreneurship Theory and Practice.

\section{CONCLUSION}

What makes failed entrepreneurs try their hand at entrepreneurship again is an interesting and important research question that has not received much systematic attention in the literature. Adopting a developmental career perspective using data from 4,761 failed entrepreneurs in Sweden, our theorizing and analyses offer intriguing new insights. Age was found to have a cubic relationship (a sideways and inverted S pattern) with the likelihood of reentry such that reentry increases during the early-career stage, decreases during the mid-career stage, and then increases during the late-career stage. In turn, the relationship between age and entrepreneurial reentry was moderated by gender and multiple-owner experience. Our findings extend the research on failed entrepreneurs and entrepreneurial career paths and will hopefully stimulate future research on failed entrepreneurs’ decision to turn to wage employment versus entrepreneurship.

\section{ACKNOWLEDGEMENTS}

We are indebted to Shaker Zahra for his initial work and contributions to earlier drafts of the paper. We wish to thank the Centre for Family Enterprise and Ownership (CeFEO) at Jönköping International Business School - Jönköping University for supporting this research and providing us access to the data. A special thanks to Mattias Nordqvist, Karin Hellerstedt and Karl Wennberg. We would also like to thank our editor Ray Bagby, the consulting editor and two anonymous reviewers for their valuable comments and suggestions. Kimberly Eddleston also thanks the Schulze Foundation and the Daniel and Dorothy Grady Fellowship to support her research. 


\section{Baù, Sieger, Eddleston, Chirico (forthcoming). Entrepreneurship Theory and Practice.}

\section{REFERENCES}

Aldrich, H. E., \& Cliff, J. E. (2003). The pervasive effects of family on entrepreneurship: Toward a family embeddedness perspective. Journal of Business Venturing, 18(5), 573-596.

Aldrich, H. E., \& Martinez, M. A. (2001). Many are called, but few are chosen: An evolutionary perspective for the study of entrepreneurship. Entrepreneurship Theory and Practice, 25(4), 41-56.

Aldwin, C., Sutton, K. J., Chiara, G., \& Spiro, A. (1996). Age differences in stress, coping and appraisal: Findings from the normative aging study. Journal of Gerontology, 51(4), 179-188.

Allison, P. D. (1984). Event history analysis: Regression for longitudinal event data. Beverly Hills, CA: Sage Publications.

Altman, E. I. (1968). Financial ratios, discriminant analysis, and the prediction of corporate bankruptcy. Journal of Finance, 23(4), 589-609.

Altman, E. I. (2000). Predicting financial distress of companies: revisiting the Z-score and ZETA models (pp. 9-12). New York, NY: Stern School of Business, New York University.

Alvarez, S. A., \& Parker, S. C. (2009). Emerging firms and the allocation of control rights: A Bayesian approach. Academy of Management Review, 34(2), 209-227.

Amaral, A. M., Baptista, R., \& Lima, F. (2011). Serial entrepreneurship: impact of human capital on time to re-entry. Small Business Economics, 37(1), 1-21.

Arregle, J.-L., Batjargal, B., Hitt, M. A., Webb, J. W., Miller, T., \& Tsui, A. S. (2015). Family Ties in Entrepreneurs' Social Networks and New Venture Growth. Entrepreneurship Theory and Practice, 39(2), 313-344.

Arvey, R. D. (1996). Job satisfaction. In N. Nicholson, R. Schuler \& A. V. d. Ven (Eds.), Encyclopedic dictionary of organizational behavior (pp. 272-274). Cambridge, UK: Blackwell.

Audretsch, D. B., Keilbach, M. C., \& Lehmann, E. E. (2006). Entrepreneurship and economic growth: Oxford University Press.

Audretsch, D. B., \& Thurik, A. R. (2001). Capitalism and democracy in the 21st century: from the managed to the entrepreneurial economy: Springer.

Bar-Tal, D., \& Frieze, I. H. (1977). Achievement motivation for males and females as a determinant of attributions for success and failure. Sex Roles, 3(3), 301-313.

Belsley, D. A., Kuh, E., \& Welsch, R. E. (2005). Regression diagnostics: Identifying influential data and sources of collinearity (Vol. 571): John Wiley \& Sons.

Betz, N. E., \& Fitzgerald, L. F. (1987). The career psychology of women: Academic Press.

Birley, S. (1985). The role of networks in the entrepreneurial process. Journal of Business Venturing, 1(1), 107-117.

Blanchard-Fields, F. (1994). Age differences in causal attributions from an adult development perspective. Journal of Gerontology, 49(2), 43-51.

Blanchflower, D. G., Oswald, A., \& Stutzer, A. (2001). Latent entrepreneurship across nations. European Economic Review, 45(4), 680-691.

Blanchflower, D. G., \& Oswald, A. J. (1998). Entrepreneurship and the youth labour market problem: a report for the OECD. Report to OECD, Paris. November.

Bradley, S. W., Aldrich, H., Shepherd, D. A., \& Wiklund, J. (2011). Resources, environmental change, and survival: Asymmetric paths of young independent and subsidiary organizations. Strategic Management Journal, 32(5), 486-509.

Brandtstadter, J., \& Renner, G. (1990). Tenacious goal pursuit and flexible goal adjustment: Explication and age-related analysis of assimilative and accommodative strategies for copin. Psychology \& Aging, 5(1), 58-67.

Brandtstadter, J., Wentura, D., \& Greve, W. (1993). Adaptive resources of the aging self: Outlines of an emergent perspective. International Journal of Behavioral Development, 16(2), 323-349.

Brim, G. (1992). Ambition: How we manage success and failure throughout our lives. New York, NY: Basic Books. 


\section{Baù, Sieger, Eddleston, Chirico (forthcoming). Entrepreneurship Theory and Practice.}

Brush, C. G. (1992). Research on Women Business Owners: Past Trends, a New Perspective and Future Directions. Entrepreneurship Theory and Practice, 16(4), 5-30.

Byrne, O., \& Shepherd, D. A. (2015). Different strokes for different folks: Entrepreneurial narratives of emotion, cognition, and making sense of business failure. Entrepreneurship Theory and Practice, 39(2), 375-405.

Castrogiovanni, G. J., Combs, J. G., \& Justis, R. T. (2006). Shifting Imperatives: An Integrative View of Resource Scarcity and Agency Reasons for Franchising. Entrepreneurship Theory and Practice, 30(1), 23-40.

Cave, F., Eccles, S., \& Rundle, M. (2001). An exploration of attitudes to entrepreneurial failure: A learning experience or an indelible stigma? Paper presented at the Babson College Entrepreneurship Research Conference, Jonkoping International Business School, Sweden.

Charles, S. T., \& Carstensen, L. L. (2007). Emotion regulation and aging. In J. J. Gross (Ed.), Handbook of emotion regulation (pp. 307-327). New York, NY: Guilford Press.

Chen, C. C., Greene, P. G., \& Crick, A. (1998). Does entrepreneurial self-efficacy distinguish entrepreneurs from managers? Journal of Business Venturing, 13(4), 295-316.

Chowdhury, S., \& Endres, M. L. (2005). Gender difference and the formation of entrepreneurial selfefficacy. Entrepreneurship in a Diverse World.

Cleves, M., Gould, W., Gutierrez, R., \& Marchenko, Y. (2008). An Introduction to Survival Analysis Using Stata. College Station, TX: Stata Press.

Cleves, M. A., Gould, W. W., Gutierrez, R. G., \& Marchenko, Y. (2010). An introduction to survival analysis using Stata. College Station, TX: Stata Press.

Cliff, J. E. (1998). Does one size fit all? exploring the relationship between attitudes towards growth, gender, and business size. Journal of Business Venturing, 13(6), 523-542.

Coad, A., Frankish, J., Roberts, R. G., \& Storey, D. J. (2013). Growth paths and survival chances: An application of Gambler's Ruin theory. Journal of Business Venturing, 28(5), 615-632.

Coate, S., \& Tennyson, S. (1992). Labor market discrimination, imperfect information and self employment. Oxford Economic Papers, 44(2), 272-288.

Cohen, A. (1991). Career stage as a moderator of the relationships between organizational commitment and its outcomes: A meta-analysis. Journal of Occupational Psychology, 64(3), 253-268.

Cooper, A. C., Folta, T. B., \& Woo, C. (1995). Entrepreneurial information search. Journal of Business Venturing, 10(2), 107-120.

Cope, J. (2005). Toward a dynamic learning perspective of entrepreneurship. Entrepreneurship Theory and Practice, 29(4), 373-397.

Cope, J. (2011). Entrepreneurial learning from failure: An interpretative phenomenological analysis. Journal of Business Venturing, 26(6), 604-623.

Cournoyer, R. J., \& Mahalik, J. R. (1995). Cross-sectional study of gender role conflict examining collegeaged and middle-aged men. Journal of Counseling Psychology, 42(1), 11-19.

Dattner, B., \& Hogan, R. (2011). Can you handle failure? Harvard business review, 89(4), 117-121, 139.

Davidsson, P., \& Honig, B. (2003). The role of social and human capital among nascent entrepreneurs. Journal of Business Venturing, 18(3), 301-331.

De Massis, A., Chirico, F., Kotlar, J., \& Naldi, L. (2014). The temporal evolution of proactiveness in family firms: The horizontal S-curve hypothesis. Family Business Review, 27(1), 35-50.

Delmar, F., \& Davidsson, P. (2000). Where do they come from? Prevalence and characteristics of nascent entrepreneurs. Entrepreneurship \& Regional Development, 12(1), 1-23.

DeMartino, R., \& Barbato, R. (2003). Differences between women and men MBA entrepreneurs: exploring family flexibility and wealth creation as career motivators. Journal of Business Venturing, 18(6), 815-832.

DeTienne, D. R. (2010). Entrepreneurial exit as a critical component of the entrepreneurial process: Theoretical development. Journal of Business Venturing, 25(2), 203-215.

DeTienne, D. R., \& Cardon, M. S. (2012). Impact of founder experience on exit intentions. Small Business Economics, 38(4), 351-374. 


\section{Baù, Sieger, Eddleston, Chirico (forthcoming). Entrepreneurship Theory and Practice.}

DeTienne, D. R., \& Chirico, F. (2013). Exit strategies in family firms: How socioemotional wealth drives the threshold of performance. Entrepreneurship Theory and Practice, 37(6), 1297-1318.

Dyer, J. W. G. (1994). Toward a Theory of Entrepreneurial Careers. Entrepreneurship Theory and Practice, 19(2), 7-21.

Dyer, W. G. (1992). The entrepreneurial experience (Vol. 22). San Francisco: Jossey-Bass.

Eddleston, K. A., \& Powell, G. N. (2008). The role of gender identity in explaining sex differences in business owners' career satisfier preferences. Journal of Business Venturing, 23(2), 244-256.

Eisenhardt, K. M., \& Tabrizi, B. N. (1995). Accelerating adaptive processes: Product innovation in the global computer industry. Administrative Science Quarterly, 40(1), 84-110.

Fairlie, R. W., \& Krashinsky, H. A. (2012). Liquidity constraints, household wealth, and entrepreneurship revisited. Review of Income and Wealth, 58(2), 279-306.

Follett, K. J., \& Hess, T. M. (2002). Agency, cognitive complexity, and the fundamental attribution error. Journal of Gerontology, 57(4), 312-323.

Francis, D. H., \& Sandberg, W. R. (2000). Friendship Within Entrepreneurial Teams and its Association with Team and Venture Performance. Entrepreneurship Theory and Practice, 25(2), 5-25.

Frankish, J. S., Roberts, R. G., Coad, A., Spears, T. C., \& Storey, D. J. (2013). Do entrepreneurs really learn? Or do they just tell us that they do? Industrial and Corporate Change, 22(1), 73-106.

Fung, H. H., \& Carstensen, L. L. (2004). Motivational changes in response to blocked goals and foreshortened time: testing alternatives to socioemotional selectivity theory. Psychology and aging, 19(1), 68-78.

Gatewood, E. J., Shaver, K. G., Powers, J. B., \& Gartner, W. B. (2002). Entrepreneurial expectancy, task effort, and performance. Entrepreneurship Theory and Practice, 27(2), 187-206.

Gibson, D. E. (2003). Developing the professional self-concept: Role model construals in early, middle, and late career stages. Organization Science, 14(5), 591-610.

Gilbert, D. T., \& Jones, E. E. (1986). Perceiver-induced constraint: Interpretations of self-generated reality. Journal of Personality and Social Psychology, 50(2), 269-280.

Gilbert, D. T., \& Malone, P. S. (1995). The correspondence bias. Psychological bulletin, 117(1), 21-38.

Gimeno, J., Folta, T. B., Cooper, A. C., \& Woo, C. Y. (1997). Survival of the fittest? Entrepreneurial human capital and the persistence of underperforming firms. Administrative Science Quarterly, 42(4), 750 783.

Gomez-Mejia, L. R., Haynes, K. T., Nunez-Nickel, M., Jacobson, K. J. L., \& Moyano-Fuentes, J. (2007). Socioemotional Wealth and Business Risks in Family-controlled Firms: Evidence from Spanish Olive Oil Mills. Administrative Science Quarterly, 52(1), 106-137.

Gordon, J. R., Beatty, J. E., \& Whelan, K. S. (1999). The midlife transition of professional women: an external and internal recalibration. Paper presented at the Academy of Management, Chicago.

Gordon, J. R., \& Whelan, K. S. (1998). Successful professional women in midlife: How organizations can more effectively understand and respond to the challenges. The Academy of Management Executive, 12(1), 8-24.

Gould, R. L. (1972). The phases of adult life: A study in developmental psychology. American Journal of Psychiatry, 129(5), 521-531.

Greller, M. M., \& Simpson, P. (1999). In search of late career: A review of contemporary social science research applicable to the understanding of late career. Human Resource Management Review, 9(3), 309-347.

Greller, M. M., \& Stroh, L. K. (1995). Careers in Midlife and Beyond - A Fallow Field in Need of Sustenance. Journal of Vocational Behavior, 47(3), 232-247.

Gross, J. J. (2008). Emotion regulation. In M. Lewis, J. M. Haviland-Jones \& L. F. Barrett (Eds.), Handbook of emotions (3rd edition ed., pp. 497-513). New York, NY: Guilford Press.

Gutek, B. A., \& Larwood, L. E. (1987). Women's career development. Thousand Oaks, CA: Sage Publications, Inc.

Hall, D. T. (1976). Careers in organizations: Goodyear Publishing Company Santa Monica, CA.

Hall, D. T. (1986). Career development in organizations. San Francisco, CA: Jossey-Bass. 


\section{Baù, Sieger, Eddleston, Chirico (forthcoming). Entrepreneurship Theory and Practice.}

Hall, D. T. (2002). Careers in and out of organizations. Thousand Oaks, CA: SAGE.

Harper, D. A. (2008). Towards a theory of entrepreneurial teams. Journal of Business Venturing, 23(6), 613-626.

Hayward, M. L., Forster, W. R., Sarasvathy, S. D., \& Fredrickson, B. L. (2010). Beyond hubris: How highly confident entrepreneurs rebound to venture again. Journal of Business Venturing, 25(6), 569-578.

Headd, B. (2003). Redefining business success: Distinguishing between closure and failure. Small Business Economics, 21(1), 51-61.

Heckhausen, H. J. (2011). Agency and control striving across the lifespan. In K. L. Fingerman, C. A. Berg, J. Smith \& T. C. Antonucci (Eds.), Handbook of Lifespan Development (pp. 183-212). New York, NY: Springer.

Heckhausen, J. (1997). Developmental regulation across adulthood: Primary and secondary control of agerelated challenges. Developmental Psychology, 33(1), 176-187.

Heckhausen, J., \& Brim, O. G. (1997). Perceived problems for self and others: self-protection by social downgrading throughout adulthood. Psychology and aging, 12(4), 610.

Heckhausen, J., \& Schulz, R. (1995). A life-span theory of control. Psychological review, 102(2), 284.

Heider, F. (1958). The psychology of interpersonal relations. New York, NY: Wiley.

Herr, E. L., \& Cramer, S. H. (1988). Career guidance and counseling through the life span: Systematic approaches. Glenview, IL: Scott, Foresman \& Co.

Hostetler, A. J., Sweet, S., \& Moen, P. (2007). Gendered career paths: A life course perspective on returning to school. Sex Roles, 56(1-2), 85-103.

Hsu, D. K., Wiklund, J., \& Cotton, R. D. (2015). Success, Failure, and Entrepreneurial Reentry: An Experimental Assessment of the Veracity of Self-Efficacy and Prospect Theory. Entrepreneurship Theory and Practice, forthcoming.

Hyytinen, A., \& Ilmakunnas, P. (2007). What distinguishes a serial entrepreneur? Industrial and Corporate Change, 16(5), 793-821.

Jenkins, A. S., Wiklund, J., \& Brundin, E. (2014). Individual responses to firm failure: Appraisals, grief, and the influence of prior failure experience. Journal of Business Venturing, 29(1), 17-33.

Jennings, J. E., \& Brush, C. G. (2013). Research on Women Entrepreneurs: Challenges to (and from) the Broader Entrepreneurship Literature? The Academy of Management Annals, 7(1), 663-715.

Jennings, J. E., \& McDougald, M. S. (2007). Work-Family Interface Experiences and Coping Strategies: Implications for Entrepreneurship Research and Practice. Academy of Management Review, 32(3), 747-760.

John, O. P., \& Gross, J. J. (2004). Healthy and unhealthy emotion regulation: Personality processes, individual differences, and life span development. Journal of personality, 72(6), 1301-1334.

Jokisaari, M. (2003). Regret appraisals, age, and subjective well-being. Journal of Research in Personality, 37(6), 487-503.

Kalleberg, A. L., \& Leicht, K. T. (1991). Gender and organizational performance: Determinants of small business survival and success. Academy of management journal, 34(1), 136-161.

Kautonen, T., Down, S., \& Minniti, M. (2014). Ageing and entrepreneurial preferences. Small Business Economics, forthcoming.

Kennedy, Q., Mather, M., \& Carstensen, L. L. (2004). The role of motivation in the age-related positivity effect in autobiographical memory. Psychological Science, 15(3), 208-214.

Kryla-Lighthall, N., \& Mather, M. (2009). The role of cognitive control in older adults' emotional wellbeing. In V. L. Bengston, D. Gans, N. Pulney \& M. Silverstein (Eds.), Handbook of theories of aging. New York, NY: Springer.

Kutner, M. H., Nachtsheim, C., \& Neter, J. (2004). Applied linear regression models (4th ed). Boston, MA: McGraw Hill.

Lachman, M. E. (2001). Handbook of midlife development. New York, NY: John Wiley.

Lam, S. S. K., Ng, T. W. H., \& Feldman, D. C. (2012). The relationship between external job mobility and salary attainment across career stages. Journal of Vocational Behavior, 80(1), 129-136. 


\section{Baù, Sieger, Eddleston, Chirico (forthcoming). Entrepreneurship Theory and Practice.}

Langowitz, N., \& Minniti, M. (2007). The Entrepreneurial Propensity of Women. Entrepreneurship Theory and Practice, 31(3), 341-364.

Lechler, T. (2001). Social interaction: A determinant of entrepreneurial team venture success. Small Business Economics, 16(4), 263-278.

Lee, S.-H., Peng, M. W., \& Barney, J. B. (2007). Bankruptcy law and entrepreneurship development: A real options perspective. Academy of Management Review, 32(1), 257-272.

Levesque, M., \& Minniti, M. (2006). The effect of aging on entrepreneurial behavior. Journal of Business Venturing, 21(2), 177-194.

Levesque, M., Shepherd, D. A., \& Douglas, E. J. (2002). Employment or self-employment: A dynamic utility-maximizing model. Journal of Business Venturing, 17(3), 189-210.

Levine, R., Gillman, M.-J., \& Reis, H. (1982). Individual differences for sex differences in achievement attributions? Sex Roles, 8(4), 455-466.

Levinson, D. J. (1978). The seasons of a man's life. New York, NY: Random House LLC.

Levinson, D. J. (1986). A conception of adult development. American psychologist, 41(1), 3-13.

Levinson, D. J., Darrow, C. M., Klein, E. B., Levinson, M. H., \& McKee, B. (1974). The psychosocial development of men in early adulthood and the mid-life transition. Life history research in psychopathology, 3(1), 243-248.

Levinson, D. J., Darrow, C. N., Klein, E. B., Levinson, M. H., \& McKee, B. (1978). The seasons of a man's life. New York, NY: Random House LLC.

Lewis, K., Harris, C., Morrison, R., Ho, M., Jawahar, I. M., \& Al Ariss, A. (2015). The entrepreneurshipmotherhood nexus: A longitudinal investigation from a boundaryless career perspective. Career Development International, 20(1), 21-37.

Luginbuhl, J. E. R., Crowe, D. H., \& Kahan, J. P. (1975). Causal attribution for success and failure. Journal of Personality and Social Psychology, 31(1), 86-93.

Martins, L. L., Eddleston, K. A., \& Veiga, J. F. (2002). Moderators of the relationship between work-family conflict and career satisfaction. Academy of Management Journal, 45(2), 399-409.

Mather, M., \& Johnson, M. K. (2000). Choice-supportive source monitoring: Do our decisions seem better to us as we age? Psychology and aging, 15(4), 596-606.

McGrath, R. G. (1999). Falling forward: Real options reasoning and entrepreneurial failure. Academy of Management Review, 24(1), 13-30.

Miller, D., \& Shamsie, J. (2001). Learning across the life cycle: Experimentation and performance among the Hollywood studio heads. Strategic Management Journal, 22(8), 725-745.

Miller, K. D., \& Reuer, J. J. (1996). Measuring organizational downside risk. Strategic Management Journal, 17(9), 671-691.

Mills, M. (2011). Introducing survival and event history analysis. London, UK: Sage Publications.

Minniti, M., \& Bygrave, W. (2001). A dynamic model of entrepreneurial learning. Entrepreneurship Theory and Practice, 25(3), 5-16.

Morita, J. G., Lee, T. W., \& Mowday, R. T. (1993). The regression-analog to survival analysis: A selected application to turnover research. Academy of Management Journal, 36(6), 1430-1464.

Newton, N., Torges, C., \& Stewart, A. (2012). Women's regrets about their lives: Cohort differences in correlates and contents. Sex Roles, 66(7-8), 530-543.

Ng, T. W. H., \& Feldman, D. C. (2007). The school-to-work transition: A role identity perspective. Journal of Vocational Behavior, 71(1), 114-134.

Nordqvist, M., Wennberg, K., Baù, M., \& Hellerstedt, K. (2013). An entrepreneurial process perspective on succession in family firms. Small Business Economics, 40(4), 1087-1122.

Ornstein, S., \& Isabella, L. (1990). Age vs Stage Models of Career Attitudes of Women - A Partial Replication and Extension. Journal of Vocational Behavior, 36(1), 1-19.

Osborne, J. W. (2015). Curvilinear effects in logistic regression. In J. W. Osborne (Ed.), Best Practices in Logistic Regression. Thousand Oaks, CA: Sage Publications.

Parker, S. C. (2004). The economics of self-employment and entrepreneurship: Cambridge University Press.

Parker, S. C. (2009). The economics of entrepreneurship. Cambridge, UK: Cambridge University Press. 


\section{Baù, Sieger, Eddleston, Chirico (forthcoming). Entrepreneurship Theory and Practice.}

Parker, S. C. (2013). Do serial entrepreneurs run successively better-performing businesses? Journal of Business Venturing, 28(5), 652-666.

Plehn-Dujowich, J. (2010). A theory of serial entrepreneurship. Small Business Economics, 35(4), 377-398.

Powell, G. N., \& Graves, L. M. (2003). Women and men in management. Thousand Oaks, CA: Sage Publications.

Powell, G. N., \& Mainiero, L. A. (1992). Cross-Currents in the River of Time - Conceptualizing the Complexities of Womens Careers. Journal of Management, 18(2), 215-237.

Praag, C. v., \& Ophem, H. V. (1995). Determinants of willingness and opportunity to start as an entrepreneur. Kyklos, 48(4), 513-540.

Quinn, J. F. (1980). Labor-force participation patterns of older self-employed workers. Social Security Bulletin, 43(4), 17-28.

Rafter, M. (2010, Apr. 15, 2010). Boomers Lead Business Startups, SecondAct.

Rees, H., \& Shah, A. (1986). An empirical analysis of self-employment in the UK. Journal of Applied Econometrics, 1(1), 95-108.

Reynolds, P. D., Carter, N. M., Gartner, W. B., \& Greene, P. G. (2004). The prevalence of nascent entrepreneurs in the United States: Evidence from the panel study of entrepreneurial dynamics. Small Business Economics, 23(4), 263-284.

Roberts, T.-A., \& Nolen-Hoeksema, S. (1989). Sex differences in reactions to evaluative feedback. Sex Roles, 21(11-12), 725-747.

Ronstadt, R. (1982). Does entrepreneurial career path really matter. Paper presented at the Babson College Entrepreneurship Research Conference, Wellesley, MA.

Rosa, P., \& Scott, M. (1996). Has firm level analysis reached its limits? Time for a rethink. International Small Business Journal, 14(4), 81-89.

Ross, C. E., \& Mirowsky, J. (2008). Age and the balance of emotions. Social Science \& Medicine, 66(12), 2391-2400.

Royston, P., \& Lambert, P. C. (2011). Flexible parametric survival analysis using Stata: beyond the Cox model. College Station, TX: Stata Press.

Ruderman, M. N., Ohlott, P. J., Panzer, K., \& King, S. N. (2002). Benefits of multiple roles for managerial women. Academy of Management Journal, 45(2), 369-386.

Sarasvathy, S. D., Menon, A. R., \& Kuechle, G. (2013). Failing firms and successful entrepreneurs: Serial entrepreneurship as a temporal portfolio. Small Business Economics, 40(2), 417-434.

Schacter, D. L. (2001). The seven sins of memory: How the mind forgets and remembers. New York, NY: Houghton Mifflin.

Schein, E. H. (1978). Career dynamics: Matching individual and organizational needs (Vol. 24). Reading, MA: Addison-Wesley.

Schjoedt, L., Monsen, E., Pearson, A., Barnett, T., \& Chrisman, J. J. (2013). New Venture and Family Business Teams: Understanding Team Formation, Composition, Behaviors, and Performance. Entrepreneurship Theory and Practice, 37(1), 1-15.

Schneer, J. A., \& Reitman, F. (1995). The Impact of Gender as Managerial Careers Unfold. Journal of Vocational Behavior, 47(3), 290-315.

Schutjens, V., \& Stam, F. (2006). Starting anew: Entrepreneurial intentions and realizations subsequent to business closure: ERIM Report Series Research in Management.

Shane, S. (2009). Why encouraging more people to become entrepreneurs is bad public policy. Small Business Economics, 33(2), 141-149.

Shepherd, D. A. (2003). Learning from business failure: Propositions of grief recovery for the selfemployed. Academy of Management Review, 28(2), 318-328.

Shepherd, D. A. (2009). Grief recovery from a loss of a family business: A multi- and meso-level theory. Journal of Business Venturing, 24(1), 81-97.

Shepherd, D. A., Covin, J. G., \& Kuratko, D. F. (2009). Project failure from corporate entrepreneurship: Managing the grief process. Journal of Business Venturing, 24(6), 588-600. 


\section{Baù, Sieger, Eddleston, Chirico (forthcoming). Entrepreneurship Theory and Practice.}

Shepherd, D. A., Douglas, E. J., \& Shanley, M. (2000). New venture survival: Ignorance, external shocks, and risk reduction strategies. Journal of Business Venturing, 15(5), 393-410.

Singh, R., \& Greenhaus, J. H. (2004). The relation between career decision-making strategies and personjob fit: A study of job changers. Journal of Vocational Behavior, 64(1), 198-221.

Singh, R. P., \& Ronch, J. L. (2011). Changing Entrepreneurial Cognitive Processes with Age: A Conceptual Discussion Based on Neuroscience. Journal of Marketing Development and Competitiveness, 5(6), 94-103.

Slocum, J. W., \& Cron, W. L. (1985). Job attitudes and performance during three career stages. Journal of Vocational Behavior, 26(2), 126-145.

Sonnenfeld, J., \& Kotter, J. P. (1982). The maturation of career theory. Human relations, 35(1), 19-46.

Sorensen, J. B., \& Fassiotto, M. A. (2011). Organizations as Fonts of Entrepreneurship. Organization Science, 22(5), 1322-1331.

Stam, E., Audretsch, D., \& Meijaard, J. (2008). Renascent Entrepreneurship. Journal of Evolutionary Economics, 18(3/4), 493-507.

Stam, E., Audretsch, D. B., \& Meijaard, J. (2009). Renascent entrepreneurship: Springer.

Staudinger, U. M. (2001). Life reflection: A social-cognitive analysis of life review. Review of General Psychology, 5(2), 148.

Stewart, A. J., \& Vandewater, E. A. (1999). "If I had it to do over again...": midlife review, midcourse corrections, and women's well-being in midlife. Journal of Personality and Social Psychology, 76(2), 270-283.

Stokes, D., \& Blackburn, R. (2002). Learning the hard way: the lessons of owner-managers who have closed their businesses. Journal of Small Business and Enterprise Development, 9(1), 17-27.

Stroh, L. K., \& Reilly, A. H. (1999). Gender and careers: Present experiences and emerging trends. Handbook of gender and work, 307-324.

Sturges, J. (1999). What it means to succeed: Personal conceptions of career success held by male and female managers at different ages. British journal of management, 10(3), 239-252.

Super, D. E. (1957). The psychology of careers (Vol. 195): New York: Harper \& Row.

Toussaint, L. L., Williams, D. R., Musick, M. A., \& Everson, S. A. (2001). Forgiveness and health: Age differences in a US probability sample. Journal of Adult Development, 8(4), 249-257.

Ucbasaran, D., Alsos, G. A., Westhead, P., \& Wright, M. (2008). Habitual Entrepreneurs. Foundations and Trends in Entrepreneurship, 4(4), 309-450.

Ucbasaran, D., Westhead, P., \& Wright, M. (2006). Habitual entrepreneurs: Edward Elgar Publishing.

Ucbasaran, D., Wright, M., \& Westhead, P. (2003). A longitudinal study of habitual entrepreneurs: starters and acquirers. Entrepreneurship \& Regional Development, 15(3), 207-228.

Valliere, D., \& Peterson, R. (2009). Entrepreneurship and economic growth: Evidence from emerging and developed countries. Entrepreneurship \& Regional Development, 21(5-6), 459-480.

Västfjäll, D., Peters, E., \& Bjälkebring, P. (2011). The experience and regulation of regret across the adult life span. In I. Nyklicek, A. Vingerhoets \& M. Zeelenberg (Eds.), Emotion regulation and wellbeing (pp. 165-180): Springer.

Venkataraman, S. (1997). The distinctive domain of entrepreneurship research. Advances in entrepreneurship, firm emergence and growth, 3(1), 119-138.

Verheul, I., Uhlaner, L., \& Thurik, R. (2005). Business accomplishments, gender and entrepreneurial selfimage. Journal of Business Venturing, 20(4), 483-518.

Wagner, J. (2005). Nascent and Infant Entrepreneurs in Germany: Evidence form the Regional Entrepreneurship Monitor (REM). Bonn, Germany: Institute for the Study of Labor.

Webster, B., \& Walker, B. (2005). Smart training for the older entrepreneur. Paper presented at the International Council of Small Business World Conference, Melbourne, Australia.

Weiner, B. (1974). Achievement motivation and attribution theory. Morristown, NJ: General Learning Corporation.

Wennberg, K., Wiklund, J., DeTienne, D. R., \& Cardon, M. S. (2010). Reconceptualizing entrepreneurial exit: Divergent exit routes and their drivers. Journal of Business Venturing, 25(4), 361-375. 


\section{Baù, Sieger, Eddleston, Chirico (forthcoming). Entrepreneurship Theory and Practice.}

Wennberg, K., Wiklund, J., Hellerstedt, K., \& Nordqvist, M. (2011). Implications of intra-family and external ownership transfer of family firms: short-term and long-term performance differences. Strategic Entrepreneurship Journal, 5(4), 352-372.

West, G. P. (2007). Collective cognition: When entrepreneurial teams, not individuals, make decisions. Entrepreneurship Theory and Practice, 31(1), 77-102.

Westhead, P., Ucbasaran, D., \& Wright, M. (2003). Differences between private firms owned by novice, serial and portfolio entrepreneurs: Implications for policy makers and practitioners. Regional Studies, 37(2), 187-200.

Westhead, P., Ucbasaran, D., Wright, M., \& Binks, M. (2005). Novice, serial and portfolio entrepreneur behaviour and contributions. Small Business Economics, 25(2), 109-132.

Westhead, P., \& Wright, M. (1998). Novice, portfolio, and serial founders: are they different? Journal of Business Venturing, 13(3), 173-204.

Wiklund, J., Baker, T., \& Shepherd, D. (2010). The age-effect of financial indicators as buffers against the liability of newness. Journal of Business Venturing, 25(4), 423-437.

Wiklund, J., Nordqvist, M., Hellerstedt, K., \& Bird, M. (2013). Internal versus external ownership transition in family firms: An embeddedness perspective. Entrepreneurship Theory and Practice, 37(6), 13191340.

Wiklund, J., \& Shepherd, D. A. (2008). Portfolio Entrepreneurship: Habitual and Novice Founders, New Entry, and Mode of Organizing. Entrepreneurship Theory and Practice, 32(4), 701-725.

Williams, C. P., \& Savickas, M. L. (1990). DEVELOPMENTAL TASKS OF CAREER MAINTENANCE. Journal of Vocational Behavior, 36(2), 166-175.

Wright, M., Robbie, K., \& Ennew, C. (1997). Venture capitalists and serial entrepreneurs. Journal of Business Venturing, 12(3), 227-249.

Wrosch, C., Heckhausen, J., \& Lachman, M. E. (2000). Primary and secondary control strategies for managing health and financial stress across adulthood. Psychology \& Aging, 15(3), 387-399.

Xavier, S. R., Kelly, D., Kew, J., Herrington, M., \& Vorderwülbecke, A. (2012). Global Entrepreneurship Monitor 2012.

Zarya, V. (2015, August 21, 2015). The fastest-growing group of entrepreneurs in the U.S.? Minority women. Fortune Magazine.

Zuckerman, D. M. (1979). Impact of Education and Selected Traits on Sex-role Related Goals and Attitudes. Journal of Vocational Behavior, 14(2), 248-254. 
Baù, Sieger, Eddleston, Chirico (forthcoming). Entrepreneurship Theory and Practice.

Table 1 - Descriptive statistics and correlations.

\begin{tabular}{|c|c|c|c|c|c|c|c|c|c|c|c|c|c|c|}
\hline & & mean & s.d. & median & 1. & 2. & 3. & 4. & 5. & 6. & 7. & 8. & 9. & VIF \\
\hline 1. & Reentry & 0.11 & 0.31 & 0.00 & & & & & & & & & & \\
\hline 2. & Age $^{a}$ & 46.71 & 10.35 & 47.00 & 0.08 & & & & & & & & & 4.32 \\
\hline 3. & Gender & 0.37 & 0.48 & 0.00 & -0.08 & -0.06 & & & & & & & & 1.03 \\
\hline 4. & Multiple-owner experience & 0.05 & 0.21 & 0.00 & 0.05 & -0.03 & -0.02 & & & & & & & 1.02 \\
\hline 5. & Education (years) & 12.02 & 2.64 & 12.00 & -0.10 & -0.16 & 0.11 & 0.00 & & & & & & 1.07 \\
\hline 6. & Entrepreneurial experience & 0.12 & 0.33 & 0.00 & 0.18 & 0.11 & -0.02 & 0.09 & -0.09 & & & & & 1.04 \\
\hline 7. & Offspring at home (age <18) & 0.46 & 0.50 & 0.00 & -0.04 & -0.29 & 0.12 & 0.04 & 0.10 & -0.02 & & & & 1.32 \\
\hline 8. & Married & 0.02 & 0.12 & 0.00 & -0.02 & -0.02 & 0.01 & 0.00 & -0.01 & -0.00 & 0.03 & & & 1.34 \\
\hline 9. & Family wealth ${ }^{\mathrm{b}}$ & 405.92 & 922.57 & 336.10 & 0.03 & 0.04 & 0.01 & 0.03 & 0.07 & 0.02 & 0.05 & -0.01 & & 1.01 \\
\hline 10 & Failed company's age (age $15+$ ) & 0.17 & 0.38 & 0.00 & 0.07 & 0.18 & -0.06 & -0.00 & -0.14 & 0.13 & -0.10 & -0.05 & 0.03 & 1.08 \\
\hline
\end{tabular}

num $=4,761$; values above .01 are significant at $\mathrm{p}<.05 .{ }^{\text {a. }}$ The VIFs calculated for the standardized values of Age2 and Age3 are 1.58 and 4.71 , respectively. ${ }^{\text {b. }}$ Value expressed in thousands of Swedish Crowns. 
Baù, Sieger, Eddleston, Chirico (forthcoming). Entrepreneurship Theory and Practice.

Table 2a - Cox Proportional Hazards Model: age, multiple-owner experience, and the probability of reentry.

\begin{tabular}{|c|c|c|c|c|}
\hline & 1. & 2. & 3. & 4. \\
\hline Education (years) & $\begin{array}{r}-0.03540 * * \\
(0.01234)\end{array}$ & $\begin{array}{r}-0.01988 \\
(0.01215)\end{array}$ & $\begin{array}{r}-0.02036+ \\
(0.01219)\end{array}$ & $\begin{array}{r}-0.01791 \\
(0.01222)\end{array}$ \\
\hline Entrepreneurial experience & $\begin{array}{r}0.66953^{* * *} \\
(0.06666)\end{array}$ & $\begin{array}{r}0.62048^{* * *} \\
(0.06670)\end{array}$ & $\begin{array}{r}0.61693 * * * \\
(0.06692)\end{array}$ & $\begin{array}{r}0.61316 * * * \\
(0.06673)\end{array}$ \\
\hline Offspring at home (age $<18$ ) & $\begin{array}{r}-0.16418^{* *} \\
(0.06032)\end{array}$ & $\begin{array}{r}-0.00681 \\
(0.06554)\end{array}$ & $\begin{array}{r}-0.02090 \\
(0.06899)\end{array}$ & $\begin{array}{r}-0.13513+ \\
(0.07123)\end{array}$ \\
\hline Married & $\begin{array}{l}1.16440 \\
(0.76910)\end{array}$ & $\begin{array}{l}1.04162 \\
(0.76926)\end{array}$ & $\begin{array}{l}1.03887 \\
(0.76927)\end{array}$ & $\begin{array}{l}1.07161 \\
(0.76929)\end{array}$ \\
\hline Family wealth & $\begin{array}{r}0.03408 * * \\
(0.01250)\end{array}$ & $\begin{array}{r}0.02973^{*} \\
(0.01322)\end{array}$ & $\begin{array}{r}0.02975^{*} \\
(0.01322)\end{array}$ & $\begin{array}{r}0.03204^{*} \\
(0.01307)\end{array}$ \\
\hline Failed company’s age (15+) & $\begin{array}{r}0.23509 * * * \\
(0.07059)\end{array}$ & $\begin{array}{r}0.15476 * \\
(0.07138)\end{array}$ & $\begin{array}{r}0.15628^{*} \\
(0.07140)\end{array}$ & $\begin{array}{r}0.15857^{*} \\
(0.07151)\end{array}$ \\
\hline Age & & $\begin{array}{r}0.02281 * * * \\
(0.00330)\end{array}$ & $\begin{array}{l}0.04058 \\
(0.02769)\end{array}$ & $\begin{array}{r}1.21849 * * * \\
(0.19024)\end{array}$ \\
\hline $\mathrm{Age}^{2}$ & & & $\begin{array}{r}-0.00019 \\
(0.00029)\end{array}$ & $\begin{array}{r}-0.02573^{* * *} \\
(0.00403)\end{array}$ \\
\hline $\mathrm{Age}^{3}$ & & & & $\begin{array}{r}0.00018^{* * *} \\
(0.00003)\end{array}$ \\
\hline Log likelihood & $-8,610.703$ & $-8,586.041$ & $-8,585.830$ & $-8,563.273$ \\
\hline $\operatorname{LR} \chi^{2}$ & $597.598^{* * *}$ & $646.923^{* * *}$ & $647.344 * * *$ & $692.458 * * *$ \\
\hline Nr. of yearly observ. & 11,185 & 11,185 & 11,185 & 11,185 \\
\hline Nr. of failed entrepr. & 4,761 & 4,761 & 4,761 & 4,761 \\
\hline Nr. of re-entry as entrepr. & 1,192 & 1,192 & 1,192 & 1,192 \\
\hline $\mathrm{AIC}^{\mathrm{a}}$ & $17,267.4$ & $17,220.1$ & $17,221.7$ & $17,180.5$ \\
\hline
\end{tabular}


Baù, Sieger, Eddleston, Chirico (forthcoming). Entrepreneurship Theory and Practice.

Table 2b - Cox Proportional Hazards Model: age, multiple-owner experience, and the probability of reentry.

\begin{tabular}{|c|c|c|c|c|}
\hline & 5. & 6. & 7. & 8. \\
\hline Education (years) & $\begin{array}{r}-0.01670 \\
(0.01219)\end{array}$ & $\begin{array}{r}-0.01623 \\
(0.01222)\end{array}$ & $\begin{array}{r}-0.01826 \\
(0.01223)\end{array}$ & $\begin{array}{r}-0.01955 \\
(0.01224)\end{array}$ \\
\hline Entrepreneurial experience & $\begin{array}{r}0.61153^{* * *} \\
(0.06673)\end{array}$ & $\begin{array}{r}0.60813^{* * *} \\
(0.06679)\end{array}$ & $\begin{array}{r}0.60164^{* * *} \\
(0.06700)\end{array}$ & $\begin{array}{r}0.59260^{* * *} \\
(0.06713)\end{array}$ \\
\hline Offspring at home (age <18) & $\begin{array}{r}-0.12287+ \\
(0.07100)\end{array}$ & $\begin{array}{r}-0.10592 \\
(0.07163)\end{array}$ & $\begin{array}{r}-0.13924^{*} \\
(0.07136)\end{array}$ & $\begin{array}{r}-0.14005^{*} \\
(0.07147)\end{array}$ \\
\hline Married & $\begin{array}{l}1.07466 \\
(0.76930)\end{array}$ & $\begin{array}{l}1.07687 \\
(0.76931)\end{array}$ & $\begin{array}{l}1.06483 \\
(0.76931)\end{array}$ & $\begin{array}{l}1.07393 \\
(0.76932)\end{array}$ \\
\hline Family wealth & $\begin{array}{r}0.03146^{*} \\
(0.01309)\end{array}$ & $\begin{array}{r}0.03214^{*} \\
(0.01309)\end{array}$ & $\begin{array}{r}0.03190^{*} \\
(0.01315)\end{array}$ & $\begin{array}{r}0.03170^{*} \\
(0.01310)\end{array}$ \\
\hline Failed company's age (15+) & $\begin{array}{r}0.15321^{*} \\
(0.07157)\end{array}$ & $\begin{array}{r}0.15422^{*} \\
(0.07175)\end{array}$ & $\begin{array}{r}0.15568^{*} \\
(0.07156)\end{array}$ & $\begin{array}{r}0.15763^{*} \\
(0.07160)\end{array}$ \\
\hline Age & $\begin{array}{r}1.21225^{* * * *} \\
(0.18985)\end{array}$ & $\begin{array}{r}1.35143 * * * \\
(0.21649)\end{array}$ & $\begin{array}{r}1.20559^{* * *} \\
(0.19072)\end{array}$ & $\begin{array}{r}1.14229 * * * \\
(0.19470)\end{array}$ \\
\hline $\mathrm{Age}^{2}$ & $\begin{array}{r}-0.02557 * * * \\
(0.00402)\end{array}$ & $\begin{array}{r}-0.02887 * * * \\
(0.00456)\end{array}$ & $\begin{array}{r}-0.02544^{* * *} \\
(0.00404)\end{array}$ & $\begin{array}{r}-0.02395 * * * \\
(0.00412)\end{array}$ \\
\hline Age $^{3}$ & $\begin{array}{r}0.00018^{* * *} \\
(0.00003)\end{array}$ & $\begin{array}{r}0.00020^{* * *} \\
(0.00003)\end{array}$ & $\begin{array}{r}0.00018^{* * * *} \\
(0.00003)\end{array}$ & $\begin{array}{r}0.00017 * * * \\
(0.00003)\end{array}$ \\
\hline Gender & $\begin{array}{r}-0.19810^{* *} \\
(0.07065)\end{array}$ & $\begin{array}{r}-0.18121^{*} \\
(0.08721)\end{array}$ & & \\
\hline Age x Gender & & $\begin{array}{r}-0.77261+ \\
(0.42694)\end{array}$ & & \\
\hline $\operatorname{Age}^{2}$ x Gender & & $\begin{array}{r}0.01810^{*} \\
(0.00924)\end{array}$ & & \\
\hline $\operatorname{Age}^{3}$ x Gender & & $\begin{array}{r}-0.00014^{*} \\
(0.00007)\end{array}$ & & \\
\hline Multiple-owner experience & & & $\begin{array}{r}0.21453 * \\
(0.10973)\end{array}$ & $\begin{array}{l}0.07380 \\
(0.16424)\end{array}$ \\
\hline Age x Multiple-owner exp. & & & & $\begin{array}{r}1.44613+ \\
(0.79551)\end{array}$ \\
\hline Age $^{2}$ x Multiple-owner exp. & & & & $\begin{array}{r}-0.03307^{*} \\
(0.01691)\end{array}$ \\
\hline Age $^{3}$ x Multiple-owner exp. & & & & $\begin{array}{r}0.00024^{*} \\
(0.00012)\end{array}$ \\
\hline Log likelihood & $-8,559.243$ & $-8,555.815$ & $-8,561.465$ & $-8,558.445$ \\
\hline $\operatorname{LR} \chi^{2}$ & $700.519 * * *$ & $707.375^{* * *}$ & $696.074^{* * *}$ & $702.114^{* * *}$ \\
\hline Number of yearly observ. & 11,185 & 11,185 & 11,185 & 11,185 \\
\hline Number of failed entrepr. & 4,761 & 4,761 & 4,761 & 4,761 \\
\hline $\begin{array}{l}\text { Number of re-entry as } \\
\text { entrepr. }\end{array}$ & 1,192 & 1,192 & 1,192 & 1,192 \\
\hline $\mathrm{AIC}^{\mathrm{a}}$ & $17,172.5$ & $17,171.6$ & $17,176.9$ & $17,176.9$ \\
\hline
\end{tabular}


Baù, Sieger, Eddleston, Chirico (forthcoming). Entrepreneurship Theory and Practice.

Figure 1 - The relationship between failed entrepreneurs' age and the probability of reentry

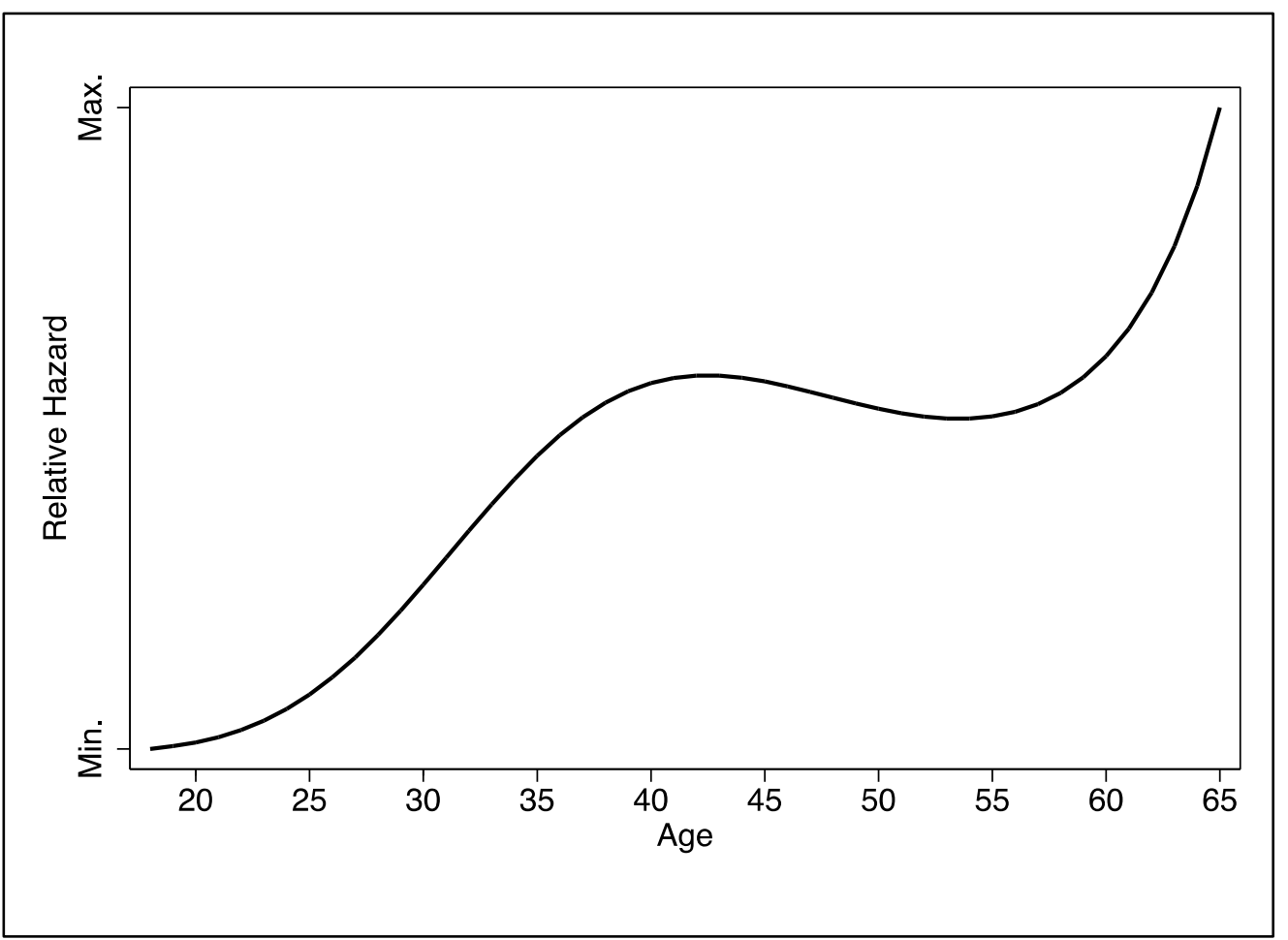

Figure 2 - The relationship between failed entrepreneurs' age and the probability of reentry for males and females

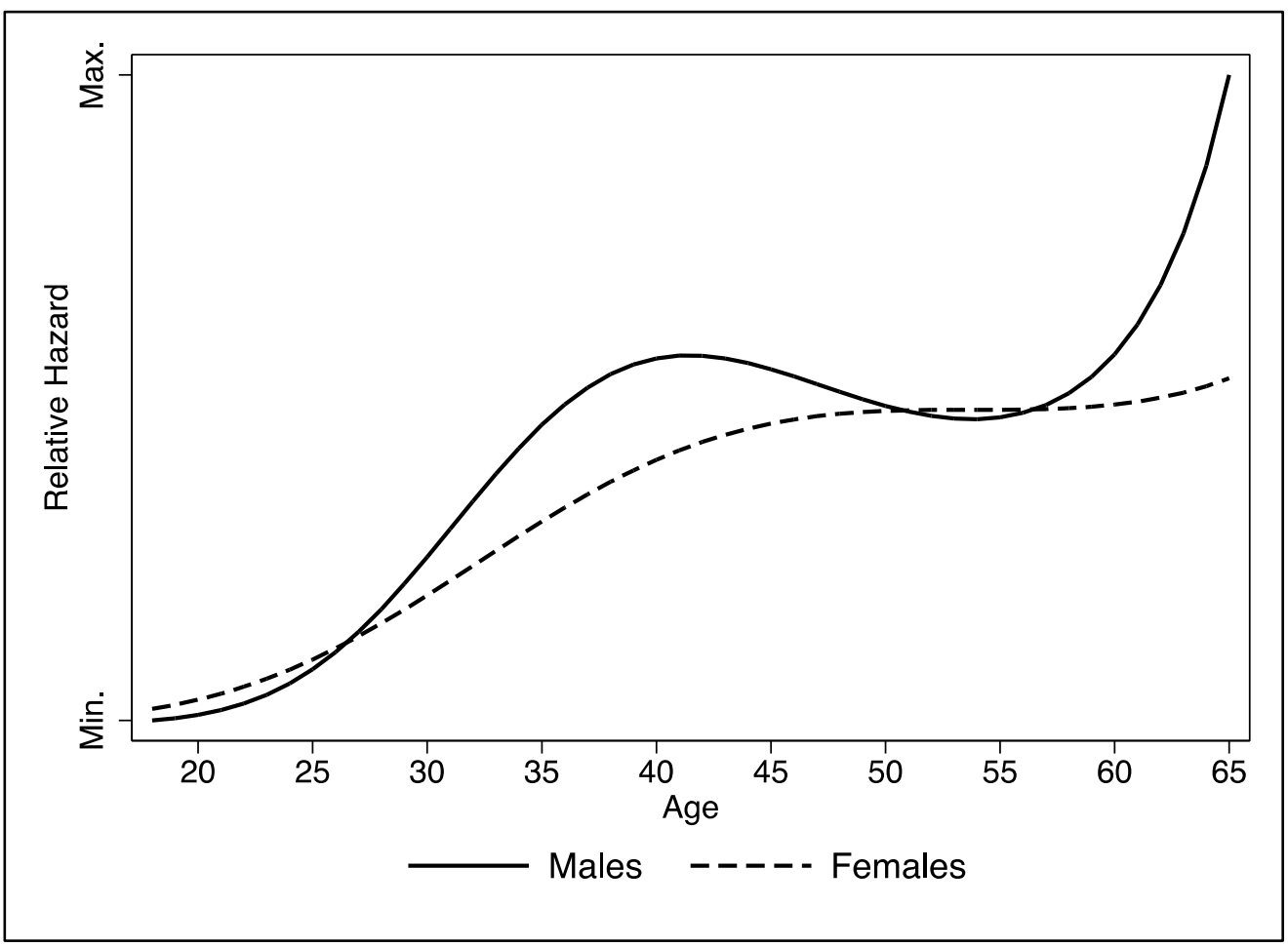


Baù, Sieger, Eddleston, Chirico (forthcoming). Entrepreneurship Theory and Practice.

Figure 3 - The relationship between failed entrepreneurs' age and the probability of reentry with and without multiple-owner experience

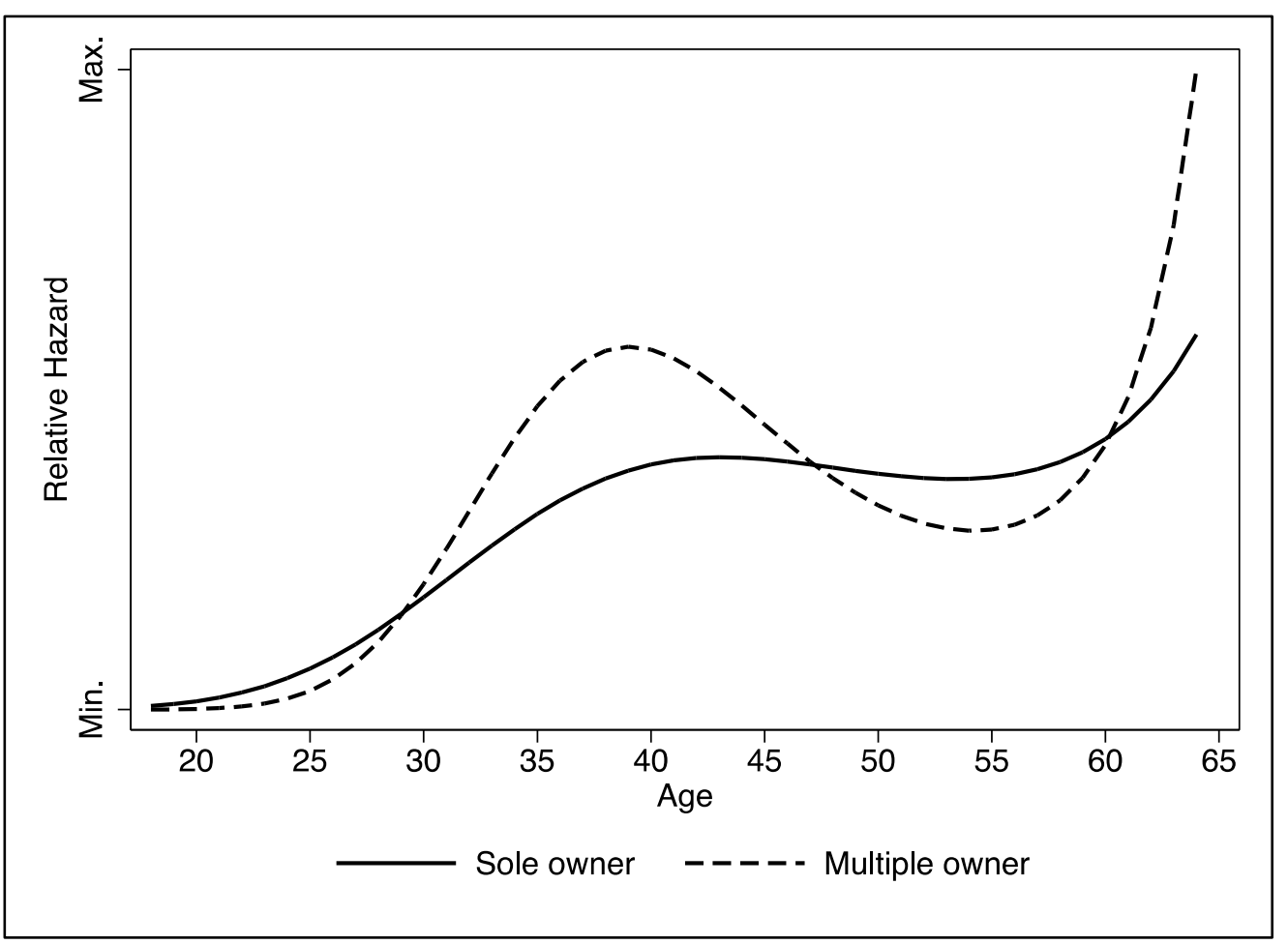

